\title{
Synthesis, Properties, and Light-Emitting Electrochemical Cell (LEEC) Device Fabrication of Cationic Ir(III) Complexes Bearing Electron- Withdrawing Groups on the Cyclometallating Ligands
}

\author{
Amlan K. Pal, ${ }^{\dagger}$ David B. Cordes, ${ }^{\ddagger}$ Alexandra M. Z. Slawin, ${ }^{\ddagger}$ Cristina Momblona, ${ }^{\S}$ Enrique Ortí, ${ }^{\S}$
} Ifor D. W. Samuel, ${ }^{\|}$Henk J. Bolink, ${ }^{\S}$ and Eli Zysman-Colman*, ${ }^{\dagger}$

\begin{abstract}
${ }^{\dagger}$ Organic Semiconductor Centre, EaStCHEM School of Chemistry, University of St Andrews, St Andrews, Fife KY16 9ST, United Kingdom

${ }^{\ddagger}$ EaStCHEM School of Chemistry, University of St Andrews, St Andrews, Fife KY16 9ST, United Kingdom

${ }^{\S}$ Instituto de Ciencia Molecular, Universidad de Valencia, C/J. Beltran 2, 46980 Paterna, Spain

"Organic Semiconductor Centre, SUPA, School of Physics and Astronomy, University of St Andrews, St Andrews, Fife KY16 9SS, United Kingdom
\end{abstract}

\section{Supporting Information}

ABSTRACT: The structure-property relationship study of a series of cationic $\operatorname{Ir}(\mathrm{III})$ complexes in the form of $\left[\operatorname{Ir}\left(\mathrm{C}^{\wedge} \mathrm{N}\right)_{2^{-}}\right.$ $(\mathrm{d} t$ Bubpy $)] \mathrm{PF}_{6} \quad\left[\right.$ where $\mathrm{d} t$ Bubpy $=4,4^{\prime}$-di-tert-butyl-2,2' bipyridine and $\mathrm{C}^{\wedge} \mathrm{N}=$ cyclometallating ligand bearing an electron-withdrawing group (EWG) at $\mathrm{C}_{4}$ of the phenyl substituent, i.e., $-\mathrm{CF}_{3}(1),-\mathrm{OCF}_{3}(2),-\mathrm{SCF}_{3}(3),-\mathrm{SO}_{2} \mathrm{CF}_{3}$ (4)] has been investigated. The physical and optoelectronic properties of the four complexes were comprehensively characterized, including by X-ray diffraction analysis. All the complexes exhibit quasireversible $\mathrm{d} t$ Bubpy-based reductions from -1.29 to $-1.34 \mathrm{~V}$ (vs SCE). The oxidation processes are

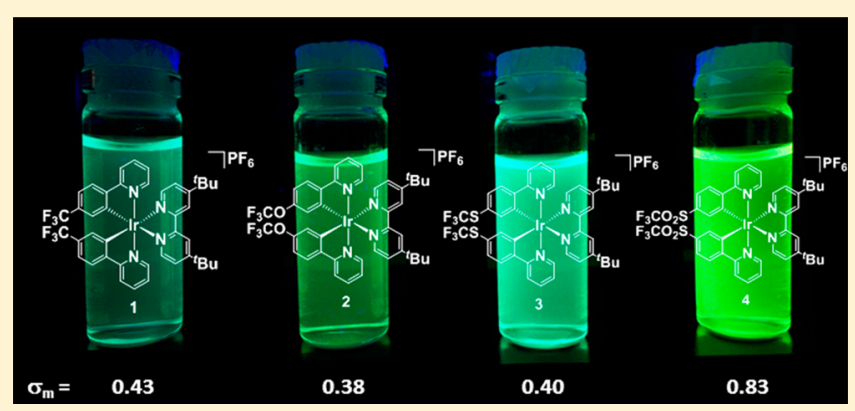
likewise quasireversible (metal $+\mathrm{C}^{\wedge} \mathrm{N}$ ligand) and are between 1.54 and $1.72 \mathrm{~V}$ (vs SCE). The relative oxidation potentials follow a general trend associated with the Hammett parameter $(\sigma)$ of the EWGs. Surprisingly, complex 4 bearing the strongest EWG does not adhere to the expected Hammett behavior and was found to exhibit red-shifted absorption and emission maxima. Nevertheless, the concept of introducing EWGs was found to be generally useful in blue-shifting the emission maxima of the complexes $\left(\lambda_{\mathrm{em}}=484-545 \mathrm{~nm}\right)$ compared to that of the prototype complex $\left[\operatorname{Ir}(\mathrm{ppy})_{2}(\mathrm{~d} t \mathrm{Bubpy})\right] \mathrm{PF}_{6}($ where ppy $=2$ phenylpyridinato $)\left(\lambda_{\mathrm{em}}=591 \mathrm{~nm}\right)$. The complexes were found to be bright emitters in solution at room temperature $\left(\Phi_{\mathrm{PL}}=45-\right.$ $66 \%)$ with microsecond excited-state lifetimes $\left(\tau_{\mathrm{e}}=1.14-4.28 \mu \mathrm{s}\right)$. The photophysical properties along with density functional theory (DFT) calculations suggest that the emission of these complexes originates from mixed contributions from ligandcentered (LC) transitions and mixed metal-to-ligand and ligand-to-ligand charge transfer (LLCT/MLCT) transitions, depending on the EWG. In complexes 1, 3, and 4 the ${ }^{3} \mathrm{LC}$ character is prominent over the mixed ${ }^{3} \mathrm{CT}$ character, while in complex 2 , the mixed ${ }^{3} \mathrm{CT}$ character is much more pronounced, as demonstrated by DFT calculations and the observed positive solvatochromism effect. Due to the quasireversible nature of the oxidation and reduction waves, fabrication of light-emitting electrochemical cells (LEECs) using these complexes as emitters was possible with the LEECs showing moderate efficiencies.

\section{INTRODUCTION}

Over the past few decades, heteroleptic cationic $\operatorname{Ir}(\mathrm{III})$ complexes have garnered widespread interest due to their frequently bright phosphorescence that can be tuned across the visible spectrum through simple ligand modification. ${ }^{1-4}$ Due to facile color tuning, high photoluminescence quantum yield $\left(\Phi_{\mathrm{PL}}\right)$ and short emission lifetimes $\left(\tau_{\mathrm{e}}\right)$, iridium complexes are ideal emissive materials for electroluminescent (EL) devices and remain the most popular materials for use in organic lightemitting diodes (OLEDs) and in light-emitting electrochemical cells (LEECs). For lighting and display applications, bright and stable red, green, and blue emitters are all required. Whereas the performance of phosphorescent red and green organometallic emitters is satisfactory, there is presently a dearth of bright and stable blue emitters for OLEDs and a nearl complete absence of blue emitters for LEECs.

Generally, two strategies are adopted to blue-shift the luminescence of cationic cyclometalated $\operatorname{Ir}(\mathrm{III})$ complexes of the form $\left[\operatorname{Ir}\left(\mathrm{C}^{\wedge} \mathrm{N}\right)_{2}\left(\mathrm{~N}^{\wedge} \mathrm{N}\right)\right]^{+}$: (a) increase the energy of the emissive metal-to-ligand, intraligand or ligand-to-ligand charge transfer state (MLCT, ILCT or LLCT, respectively) by

Received: July 5, 2016

Published: September 28, 2016 
Chart 1. Chemical Structures of Ligands L1-L4 and Cationic Ir(III) Complexes 1-4 under Discussion<smiles>FC(F)(F)c1ccc(-c2ccccn2)cc1</smiles>

L1<smiles>FC(F)(F)Oc1ccc(-c2ccccn2)cc1</smiles>

L2<smiles>FC(F)(F)c1ccc(-c2ccccn2)cc1</smiles>

L3<smiles>O=S(=O)(OC(F)(F)F)c1ccc(-c2ccccn2)cc1</smiles>

L4

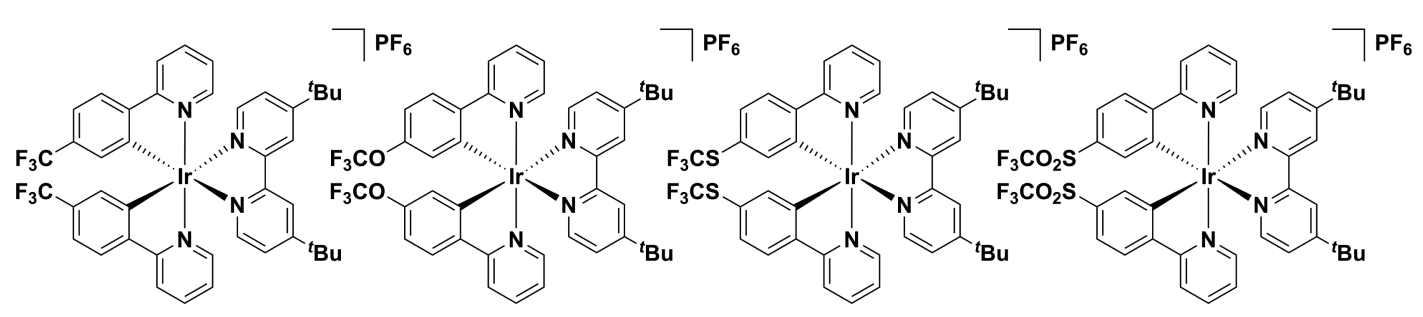

1

2

3

4

Chart 2. Chemical Structures of Benchmark Cationic Ir(III) Complexes R1-R6 under Discussion

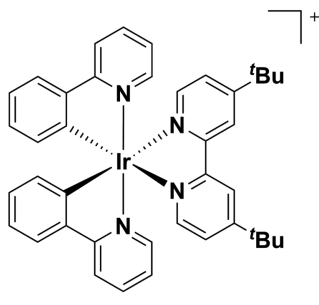

R1

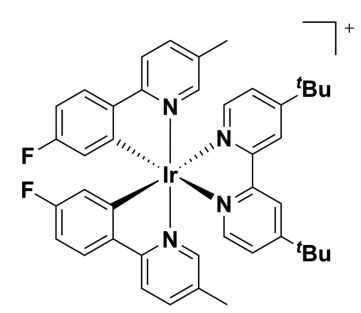

R4

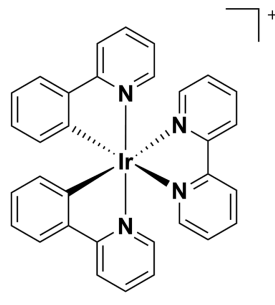

R2

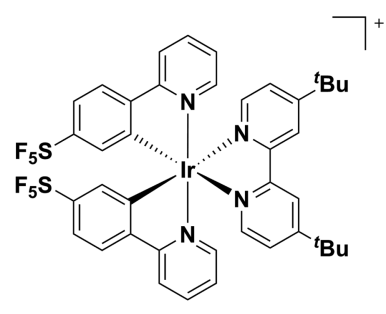

R5

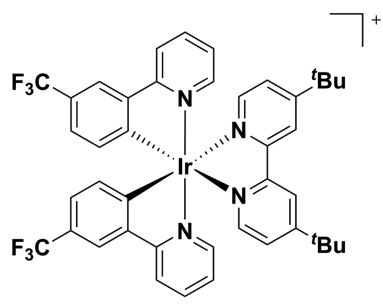

R3

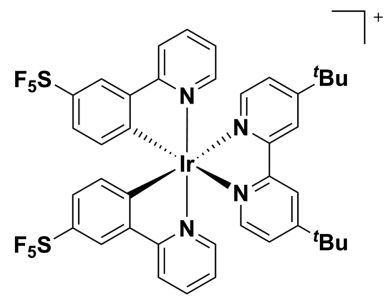

R6 introducing electron-donating groups (EDGs) on the ancillary $\mathrm{N}^{\wedge} \mathrm{N}$ ligand or electron-withdrawing groups (EWGs) on the cyclometallating $\mathrm{C}^{\wedge} \mathrm{N}$ ligands; ${ }^{5}$ and (b) increase the energy of the emissive $\pi-\pi^{*}$ ligand-centered states by limiting conjugation within the ligand. ${ }^{6,7}$ With EWGs positioned on the $\mathrm{C}^{\wedge} \mathrm{N}$ ligands, the HOMO is stabilized more than the LUMO, which translates to an increased band gap and, generally, bluer emission. Currently, it is a near-universal strategy to employ $\mathrm{C}^{\wedge} \mathrm{N}$ ligands like 2-(4,6-difluorophenyl)-pyridine, dFppy, to obtain blue/blue-green-emitting Ir complexes in solution, a subset of which have been used in LEECs. ${ }^{8-16}$ While the Ir(III) complexes containing fluorinated $\mathrm{C}^{\wedge} \mathrm{N}$ ligands exhibit sky-blue to blue emission, they are prone to degradation via defluorination. ${ }^{17,18}$ Thus, while the presence of fluorine atoms on the $\mathrm{C}^{\wedge} \mathrm{N}$ ligands blue-shifts the emission, its deleterious effect on device lifetime mitigates against its inclusion in the emitter design. Apart from fluorination, the other EWGs that have been used to blue-shift the phosphorescence of $\operatorname{Ir}(\mathrm{III})$ complexes include the following: sulfonyl $\left(-\mathrm{SO}_{2} \mathrm{R}\right),{ }^{19,20}$ trifluoromethyl $\left(-\mathrm{CF}_{3}\right),{ }^{21-25}$ pentafluoro- $\lambda_{6}$-sulfanyl $\left(\mathrm{SF}_{5}\right){ }^{26}$ and cyclometalated heterocycles such as $2,3^{\prime}$-bipyridinato. ${ }^{27-33}$ Sky-blue and deep-blue emitting cationic Ir(III) complexes bearing biimidazole, ${ }^{34-36}$ bis(NHC), ${ }^{37}$ substituted triazole or tetrazole, ${ }^{38-40}$ or pyrazolyl-pyridine ${ }^{10}$ as ancillary ligands have also been explored, but challenges still remain regarding efficiencies and stabilities of these emitters in devices, primarily as a consequence of thermal population of metal-centered states $\left({ }^{3} \mathrm{MC}\right){ }^{41}$ Thus, there is still a demand for blue-emitting phosphors as emitters in lighting devices.

Among various other EWGs, ${ }^{42}$ those that find interest in organometallic chemistry are fluorocarbon groups, given the fact that these groups are bulky, polar, hydrophobic, and chemically inert. They are therefore attractive for reducing interactions between iridium complexes, which could otherwise lead to aggregation-induced broadening and red-shifting of the phosphorescence. $^{43-47}$ This is particularly important in blue electroluminescent devices and in particular LEECs as the lightemitting layer is often a neat film. Tuning of optoelectronic properties in organometallic Ir(III) complexes using bulky fluorocarbon groups is also relatively rare compared to those with other transition metal ions. ${ }^{21,25,39,45,47-49}$ Thus, stable, bulky, and electron-withdrawing fluorocarbon groups are desirable alternatives to the commonly used C(aryl)-F motif and should serve the similar purpose of fine-tuning of optoelectronic properties of their $\operatorname{Ir}($ III) complexes.

Herein we report a systematic and comparative synthetic, structural, electrochemical, and spectroscopic study of phosphorescent $\operatorname{Ir}(\mathrm{III})$ complexes with a series of electron- 
Scheme 1. Synthesis of $C^{\wedge} N$ Ligands, L1-L4, and $\left[\operatorname{Ir}\left(C^{\wedge} N\right)_{2}(d t B u b p y)\right] P F_{6}$ Complexes, 1-4

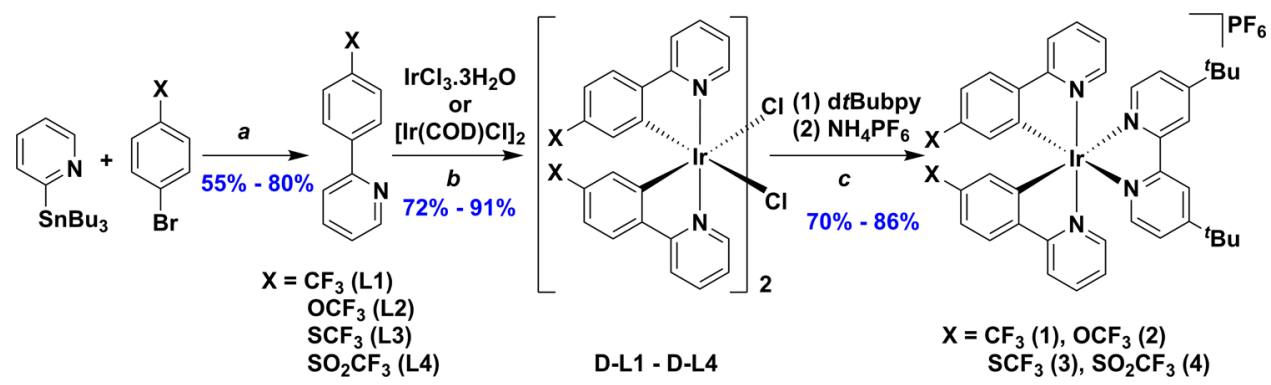

${ }^{a}$ Reagents and conditions: $1.6-2 \mathrm{~mol} \% \mathrm{Pd}\left(\mathrm{PPh}_{3}\right)_{4}, \mathrm{~N}_{2}$, dry degassed PhMe $(10-15 \mathrm{~mL}), 120{ }^{\circ} \mathrm{C}, 24-48 \mathrm{~h} .{ }^{b} 2-\mathrm{EtOC}_{2} \mathrm{H}_{4} \mathrm{OH} / \mathrm{H}_{2} \mathrm{O}(3: 1 \mathrm{v} / \mathrm{v})$ or 2 EtOC ${ }_{2} \mathrm{H}_{4} \mathrm{OH}(4 \mathrm{~mL}), 120-130{ }^{\circ} \mathrm{C}, \mathrm{N}_{2}, 5-24$ h. ${ }^{c}(1) \mathrm{CH}_{2} \mathrm{Cl}_{2} / \mathrm{MeOH}(5: 1 \mathrm{v} / \mathrm{v}), 40{ }^{\circ} \mathrm{C}, 24 \mathrm{~h}, \mathrm{~N}_{2}$, (2) excess aqueous $\mathrm{NH}_{4} \mathrm{PF}_{6}$.
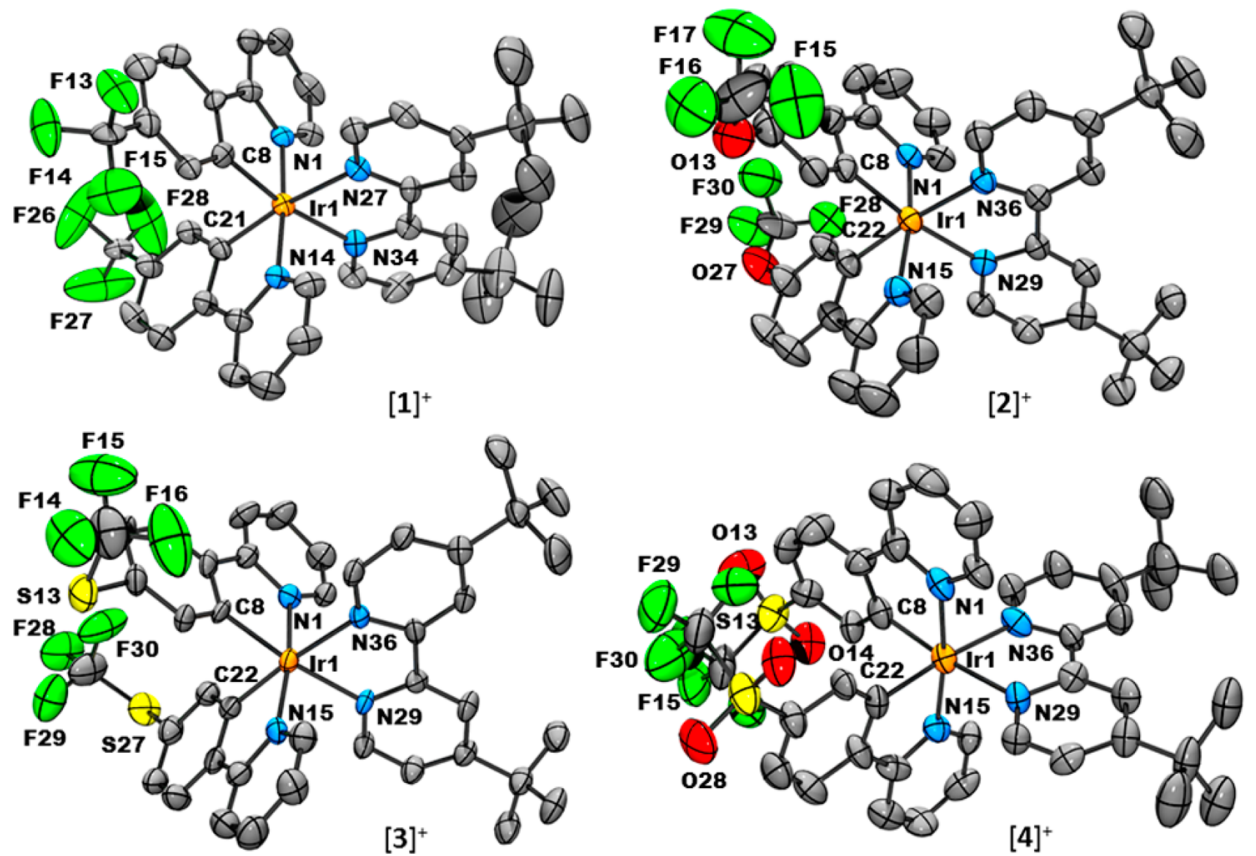

Figure 1. Solid-state structures of complexes 1-4. Hydrogen atoms, $\mathrm{PF}_{6}^{-}$counterions, solvent molecules, minor components of disordered molecules, and additional independent molecules are omitted for clarity. Thermal ellipsoids correspond to a 50\% probability level.

withdrawing fluorocarbon groups attached at the 4-position of the $\mathrm{C}^{\wedge} \mathrm{N}$ ligands (ligands $\mathbf{L} \mathbf{1}-\mathbf{L} \mathbf{4}$ in Chart 1 ), including the following: trifluoromethyl $\left(-\mathrm{CF}_{3}\right)$, trifluoromethoxy $\left(-\mathrm{OCF}_{3}\right)$, trifluoromethylsulfanyl $\left(-\mathrm{SCF}_{3}\right)$, and trifluoromethylsulfonyl $\left(-\mathrm{SO}_{2} \mathrm{CF}_{3}\right)$. These $\mathrm{C}^{\wedge} \mathrm{N}$ ligands were used in combination with the electron-donating 4,4'-di-tert-butyl-2,2'-bipyridine ( $\mathrm{d} t$ Bubpy) as the ancillary $\mathrm{N}^{\wedge} \mathrm{N}$ ligand (complexes 1-4 in Chart 1). The effects of the presence of different EWGs on the optoelectronic properties in conjunction with density functional theory (DFT) calculations are discussed, and the results are compared with six benchmark complexes (complexes R1R6 in Chart 2) along with the application of the new complexes in LEECs as solid-state lighting devices.

\section{RESULTS AND DISCUSSION}

Synthesis. The syntheses of the $C^{\wedge} \mathrm{N}$ ligands L1-L4 and the heteroleptic iridium complexes 1-4 are shown in Scheme 1. Each of the substituted $\mathrm{C}^{\wedge} \mathrm{N}$ ligands was prepared in high yield via Stille palladium-catalyzed cross-coupling reaction in moderate to good yield. ${ }^{50}$ Ligands $\mathbf{L} \mathbf{1}$ and $\mathbf{L} \mathbf{2}$ were synthesized following literature procedure. ${ }^{51}$ The tin byproducts were removed by passing the reaction mixture through silica gel and
(10 wt \%) potassium carbonate. ${ }^{52}$ The $\mathrm{C}^{\wedge} \mathrm{N}$ ligands, L1-L4, were complexed with either $\operatorname{IrCl}_{3} \cdot 3 \mathrm{H}_{2} \mathrm{O}$ or $[\operatorname{Ir}(\mathrm{COD})(\mu-\mathrm{Cl})]_{2}$ (where $\mathrm{COD}=1,5$-cyclooctadiene) and the resulting $\mu$ dichloro-bridged iridium dimers $\left[\operatorname{Ir}(\mathbf{L 1})_{2}(\mu-\mathrm{Cl})\right]_{2}$, D-L1; [Ir$\left.(\mathbf{L 2})_{2}(\mu-\mathrm{Cl})\right]_{2}, \mathbf{D}-\mathbf{L} 2 ;\left[\operatorname{Ir}(\mathbf{L} 3)_{2}(\mu-\mathrm{Cl})\right]_{2}, \mathbf{D}-\mathbf{L} 3$; and $\left[\operatorname{Ir}(\mathbf{L} 4)_{2}(\mu-\right.$ $\mathrm{Cl})]_{2}$, D-L4 were formed in good yields under standard conditions $^{53}$ and were used without further purification. The heteroleptic cationic iridium(III) complexes 1-4 were isolated in high yields through cleavage of D-L1 - D-L4 with the $\mathrm{d} t$ Bubpy ligand. All cationic complexes were purified by column chromatography and isolated as the $\mathrm{PF}_{6}{ }^{-}$salt following an anion metathesis reaction using aqueous $\mathrm{NH}_{4} \mathrm{PF}_{6}$. Complexes 1-4 are air- and moisture-stable solids that are soluble in polar organic solvents including acetonitrile and dichloromethane.

The ligands L1-L4, dimers D-L1-D-L4, and cationic complexes 1-4 were characterized by ${ }^{1} \mathrm{H}$ and ${ }^{19} \mathrm{~F}$ NMR spectroscopy (see Figures S1-S6 for stacked NMR spectra and Figures S7-S37 for individual NMR spectra), HRMS, melting point determination, and elemental analyses. Complexes 1-4 were further characterized by single crystal X-ray structural analysis. Inherent $C_{2}$ symmetry in the solution state of complexes 1-4 was confirmed by both ${ }^{1} \mathrm{H}$ and ${ }^{19} \mathrm{~F}$ NMR 
Table 1. Redox Data of Complexes 1, 2, 3, and 4 in Degassed $\mathrm{MeCN}^{a}$

\begin{tabular}{|c|c|c|c|c|c|c|c|c|}
\hline \multirow[b]{2}{*}{ compd } & \multirow[b]{2}{*}{$E_{1 / 2}^{\text {ox }}(\Delta E \mathrm{p})$} & \multirow[b]{2}{*}{$E_{1 / 2}{ }^{\text {red }}(\Delta E \mathrm{p})$} & \multirow[b]{2}{*}{$\Delta E_{\text {redox }}^{b}$} & \multirow[b]{2}{*}{$E_{\text {Номо }}^{c}$} & \multirow[b]{2}{*}{$E_{\text {LUMO }}{ }^{c}$} & \multirow[b]{2}{*}{$\left|E_{\text {LUMO-HOMO }}\right|^{c}$} & \multicolumn{2}{|c|}{ Hammett constant $(\sigma)$} \\
\hline & & & & & & & $\sigma_{\mathrm{m}}$ & $\sigma_{\mathrm{p}}$ \\
\hline 1 & $1.60(70)$ & $-1.33(72)$ & 2.93 & -5.87 & -2.39 & 3.48 & 0.43 & 0.54 \\
\hline 2 & $1.54(128)$ & $-1.34(115)$ & 2.88 & -5.76 & -2.35 & 3.41 & 0.38 & 0.35 \\
\hline 3 & $1.58(82)$ & $-1.31(78)$ & 2.89 & -5.83 & -2.37 & 3.46 & 0.40 & 0.50 \\
\hline 4 & $1.72(90)$ & $-1.29(104)$ & 3.01 & -6.13 & -2.45 & 3.68 & 0.83 & 0.96 \\
\hline $\mathbf{R} \mathbf{1}^{d}$ & $1.29(106)$ & $-1.42(87)$ & 2.71 & -5.56 & -2.29 & 3.27 & & \\
\hline $\mathbf{R} 3^{e}$ & $1.59(88)$ & $-1.36(83)$ & 2.95 & & & & & 0.54 \\
\hline $\mathbf{R 5}^{f}$ & $1.65(68)$ & & & & & & 0.61 & \\
\hline $\mathbf{R} 6^{f}$ & $1.66(68)$ & & & & & & & 0.68 \\
\hline
\end{tabular}

${ }^{a}$ Potentials are in volts $(\mathrm{V})$ vs SCE for acetonitrile solutions, $0.1 \mathrm{M}$ in $\left[n-\mathrm{Bu}_{4} \mathrm{~N}\right] \mathrm{PF}_{6}$, recorded at room temperature at a sweep rate of $100 \mathrm{mV} / \mathrm{s}$ using a glassy carbon electrode as the working electrode, a platinum wire as the counter electrode, and a silver wire as the reference electrode. The difference between cathodic, $E_{\mathrm{pc}}$ and anodic, $E_{\mathrm{pa}}$ peak potentials, $\Delta E_{\mathrm{p}}(\mathrm{mV})$ is given in parentheses. ${ }^{b} \Delta E_{\text {redox }}$ is the difference $(\mathrm{V})$ between first oxidation and first reduction potentials. ${ }^{c} \mathrm{DFT}$ calculated energy in $\mathrm{eV}$. ${ }^{d}$ From ref 57 (a correction factor of $0.38 \mathrm{~V}$ instead of $0.4 \mathrm{~V}$ as reported in the literature has been applied for direct comparison). ${ }^{e}$ From ref 58 (a correction factor of $0.38 \mathrm{~V}$ has been applied for direct comparison). ${ }^{55} f_{\text {From }}$ ref 26 (a correction factor of $0.38 \mathrm{~V}$ has been applied for direct comparison). ${ }^{55}$

spectroscopy. The effect of the EWG on the electronics of the phenyl ring is pronounced, evidenced by the gradual and linear downfield shift of the proton ortho to the nitrogen atom of the pyridyl ring of the $\mathrm{C}^{\wedge} \mathrm{N}$ ligands from complex 2 to 3 to $\mathbf{1}$ to 4 (Figure $\mathrm{S} 5$ ) in accordance with the increasing Hammett constant $\left(\sigma_{\mathrm{m}}\right)$ from $-\mathrm{OCF}_{3}(0.38)$ to $-\mathrm{SCF}_{3}(0.40)$ to $-\mathrm{CF}_{3}$ (0.43) to $-\mathrm{SO}_{2} \mathrm{CF}_{3}(0.83)$ as calculated by Hansch et al. (Figure S38). ${ }^{42}$ The ${ }^{19} \mathrm{~F}$ NMR spectra exhibit the characteristic singlet peak in the range $-42 \mathrm{ppm}$ to $-80 \mathrm{ppm}$ for a substituted $-\mathrm{CF}_{3}$ group and a doublet $(J=713 \mathrm{~Hz}$ at $400 \mathrm{MHz}$ instrument due to ${ }^{31} \mathrm{P}-{ }^{19} \mathrm{~F}$ nuclear coupling) at $\sim-73 \mathrm{ppm}$ for the six magnetically equivalent fluorine atoms in the $\mathrm{PF}_{6}{ }^{-}$anion (Figure S6). The HRMS analyses of $\mathbf{L 2}-\mathbf{L} 4$ and $\mathbf{1 - 4}$ showed the diagnostic peaks of the protonated ligand $\left[\mathrm{M}+\mathrm{H}^{+}\right]$and the cation $\left[\operatorname{Ir}\left(\mathrm{C}^{\wedge} \mathrm{N}\right)_{2}(\mathrm{~d} t \text { Bubpy })\right]^{+}$, respectively (Figures S39-S45).

Crystal Structures. Crystals of the complexes, suitable for $\mathrm{X}$-ray analysis, were grown by slow diffusion of diethyl ether into moderately concentrated solutions of the complexes in dichloromethane (1 and 2) and by slow evaporation of mixed solutions of $\mathrm{CH}_{2} \mathrm{Cl}_{2} /$ heptanes (3) or $\mathrm{CH}_{2} \mathrm{Cl}_{2} /$ hexanes (4) (Figure 1). Selected crystallographic parameters are tabulated in Table S1. Selected bond distances and angles in comparison to those predicted by DFT calculations are summarized in Table S2. In each of the complexes, the Ir(III) ion exhibits a coordinatively saturated distorted octahedral coordination environment with the two $\mathrm{N}$ atoms of the $\mathrm{C}^{\wedge} \mathrm{N}$ ligands trans to each other, similar to the solid-state structure of the archetypal complex R2. ${ }^{54}$ The average $\operatorname{Ir}-\mathrm{C}_{\text {ppy }}(2.015 \AA)$ and $\mathrm{Ir}-\mathrm{N}_{\mathrm{ppy}}(2.050 \AA)$ bond distances in $\mathbf{1 - 4}$ are similar to those in complex R2 ( $\mathrm{Ir}-\mathrm{C}_{\mathrm{ppy}}: 2.013 \AA$; $\mathrm{Ir}-\mathrm{N}_{\mathrm{ppy}}: 2.045 \AA$ ). In each of the four complexes, the $\mathrm{Ir}-\mathrm{N}$ bond to the ancillary $\mathrm{d} t \mathrm{Bubpy}$ ligand $[2.113(10)-2.134(9) \AA]$ is longer than that to the $\mathrm{C}^{\wedge} \mathrm{N}$ ligands $[2.039(4)-2.061(11) \AA]$, and the $\mathrm{N}_{\mathrm{N}^{\wedge} \mathrm{N}}-\mathrm{Ir}-\mathrm{N}_{\mathrm{N}^{\wedge} \mathrm{N}}$ bite angle $\left[75.89(15)-76.8(4)^{\circ}\right]$ is narrower than that of $\mathrm{C}_{\mathrm{C}^{\wedge} \mathrm{N}}-\mathrm{Ir}-$ $\mathrm{N}_{\mathrm{C}^{\wedge} \mathrm{N}}\left[80.1(3)-80.6(4)^{\circ}\right]$. The DFT calculated bond distances and angles are in line with those observed for the solid-state structures. In all the complexes, the presence of bulky substituents in the cyclometallating ligand and the $t \mathrm{Bu}$ groups onto the backbone of the bipyridine unit prevents any face-toface $\pi-\pi$ stacking of the complexes.

Electrochemical Properties. The electrochemical properties of the ligands and mononuclear complexes have been investigated by both cyclic and differential pulse voltammetry (CV and DPV, respectively) in degassed $\mathrm{MeCN}$, and the first redox potentials, reported with respect to $\mathrm{SCE}\left(\mathrm{Fc} / \mathrm{Fc}^{+}=0.38\right.$ $\mathrm{V}$ in $\mathrm{MeCN}),{ }^{55}$ are compiled in Table 1 , while the full set of redox potentials are detailed in Table S3, and the CVs along with DPVs are shown in Figure 2. Electrochemistry data of R1,

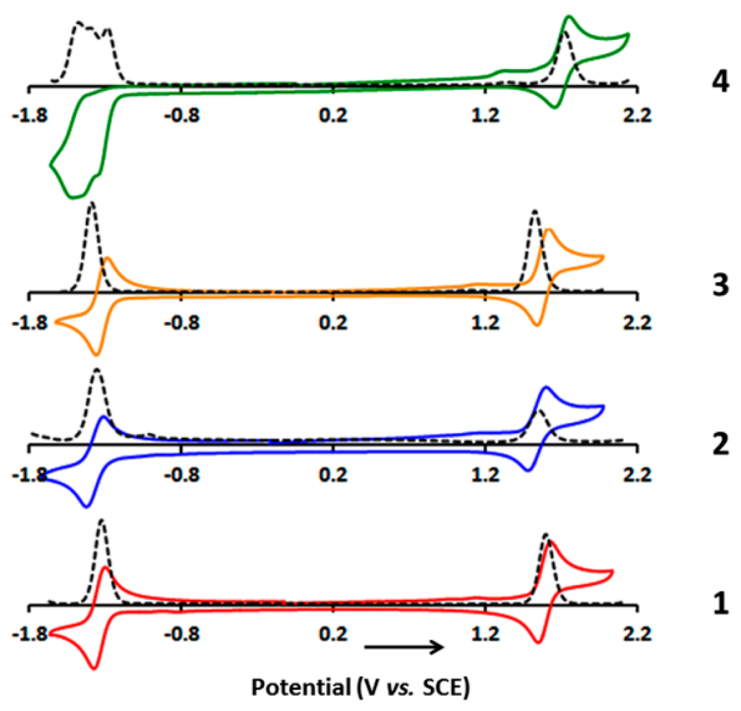

Figure 2. Cyclic voltammograms (solid) and differential pulse voltammograms (dotted) of complexes 1, 2, 3, and 4 in degassed $\mathrm{MeCN}$, recorded at a scan rate of $100 \mathrm{mV} / \mathrm{s}$.

R3, R5, and R6 have been corrected to account for the experimental setup and referencing versus SCE (see Electrochemistry section in the Supporting Information for full details).

At positive potential, complexes 1-4 exhibit a quasireversible single electron oxidation between 1.54 and $1.72 \mathrm{~V}$. DFT calculations using the B3LYP functional indicate that incorporation of various electron-withdrawing groups results in a stabilization of the HOMOs (HOMO = highest occupied molecular orbital) of complexes 1-4 compared to that of reference complex $\mathbf{R} \mathbf{1}$ and the HOMOs of these complexes are almost equally constituted of the metal center as well as the $\mathrm{C}^{\wedge} \mathrm{N}$ ligands (Figure 3 ). Thus, and also following literature data of structurally similar cationic Ir(III) complexes, ${ }^{4,56}$ the oxidation potentials of complexes $\mathbf{1 - 4}$ are assigned to the removal of an electron from an admixture of the (metal + 


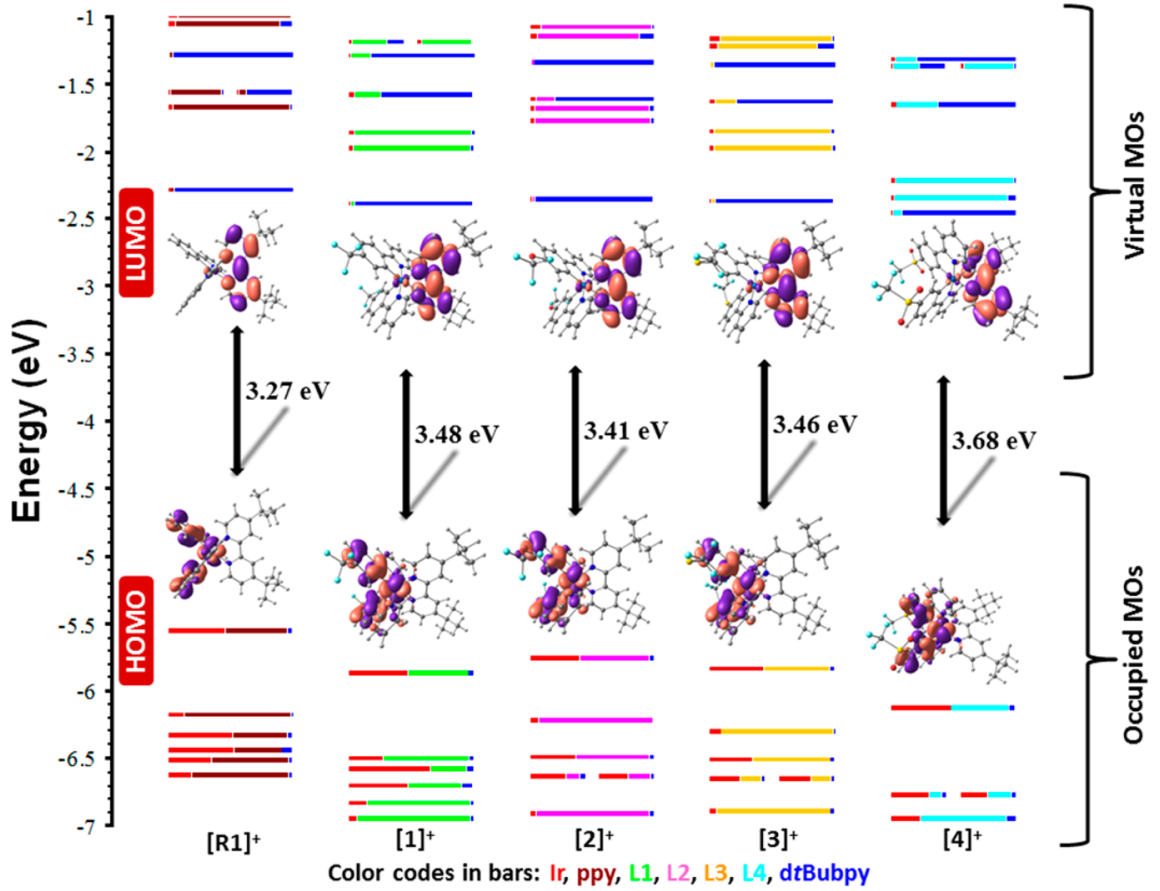

Figure 3. Calculated frontier MO energies of $[1]^{+},[2]^{+},[3]^{+},[4]^{+}$, and $[\mathbf{R 1}]^{+}$, obtained from DFT $\left[\left(\mathrm{B} 3 \mathrm{LYP} / \mathrm{SBKJC}-\mathrm{VDZ}\right.\right.$ for Ir(III)) and $\left(6-31 \mathrm{~g}^{* *}\right.$ for $\mathrm{C}, \mathrm{H}, \mathrm{N},(\mathrm{O}), \mathrm{F},(\mathrm{S})]$ with $\mathrm{CPCM}\left(\mathrm{CH}_{3} \mathrm{CN}\right)$ and $0.5 \mathrm{eV}$ threshold of degeneracy (orbitals are isocontoured at 0.03$)$. Kohn-Sham MOs of $[\mathbf{1}]^{+}$, $[2]^{+},[3]^{+},[4]^{+}$, and $[\mathbf{R} \mathbf{1}]^{+}$are also shown.

$\left.\mathrm{C}^{\wedge} \mathrm{N}\right)$-based orbitals. The lower energies calculated for the HOMOs of $1\left(E_{\mathrm{HOMO}}=-5.87 \mathrm{eV}\right), 2\left(E_{\mathrm{HOMO}}=-5.76 \mathrm{eV}\right), 3$ $\left(E_{\mathrm{HOMO}}=-5.83 \mathrm{eV}\right)$, and $4\left(E_{\mathrm{HOMO}}=-6.13 \mathrm{eV}\right)$ compared to that of R1 $\left(E_{\text {HOMO }}=-5.56 \mathrm{eV}\right)$ are in good agreement with the higher anodic potentials measured for complexes 1-4 in comparison to that of $\mathbf{R} \mathbf{1}$ (Table 1). The $-\mathrm{SO}_{2} \mathrm{CF}_{3}$ substituted ppy moiety (L4) in complex 4 acts as the strongest electronwithdrawing group (EWG) compared to $-\mathrm{CF}_{3},-\mathrm{OCF}_{3}$, and $-\mathrm{SCF}_{3}$, as demonstrated by the highest oxidation potential of this complex, while the $-\mathrm{OCF}_{3}$ substituted ppy moiety (L2) acts as the poorest EWG. This fact is in line with the increasing energy of the HOMO from complexes 4 to 1 to 3 to 2 as calculated by DFT and also in good agreement with the higher Hammett meta-constant $\left(\sigma_{\mathrm{m}}\right)$ of the $-\mathrm{SO}_{2} \mathrm{CF}_{3}$ group (0.83) compared to $-\mathrm{CF}_{3}(0.43),-\mathrm{SCF}_{3}(0.40)$, and $-\mathrm{OCF}_{3}(0.38)$ groups. ${ }^{42}$ A linear relationship $\left(R^{2}=0.93\right)$ was found between the Hammett constants of the different EWGs of 1-4, those found on the reference complexes, and the oxidation potentials of the corresponding complexes (Figure 4).

Upon scanning to negative potential, several ligand-based reductions are exhibited by complexes 1-4. While for complexes 1, 3, and 4, the first reductions are monoelectronic, for complex 2 this reduction is found to be dielectronic as inferred from the DPVs of these complexes (Figure 2). The reduction profile of $\mathbf{4}$ was found to be irreversible while the reduction for $\mathbf{1 - 3}$ was quasireversible in nature, thus suggesting an electrochemical instability of 4 . DFT calculations point to a LUMO (LUMO = lowest unoccupied molecular orbital) that has predominantly $\mathrm{d} t$ Bubpy character. Therefore, the first reduction can unambiguously be assigned to reduction of the d $t$ Bubpy moiety, while LUMO +1 and LUMO +2 are localized mainly on the L1-L4 ligands. Thus, in a coarse approximation, the second and third reduction waves may be assigned to reduction of the $\mathbf{L} \mathbf{1}-\mathbf{L} \mathbf{4}$ moieties. Unlike the other EWGs found in $1-3$, the strongest $-\mathrm{SO}_{2} \mathrm{CF}_{3}$ EWG group in 4

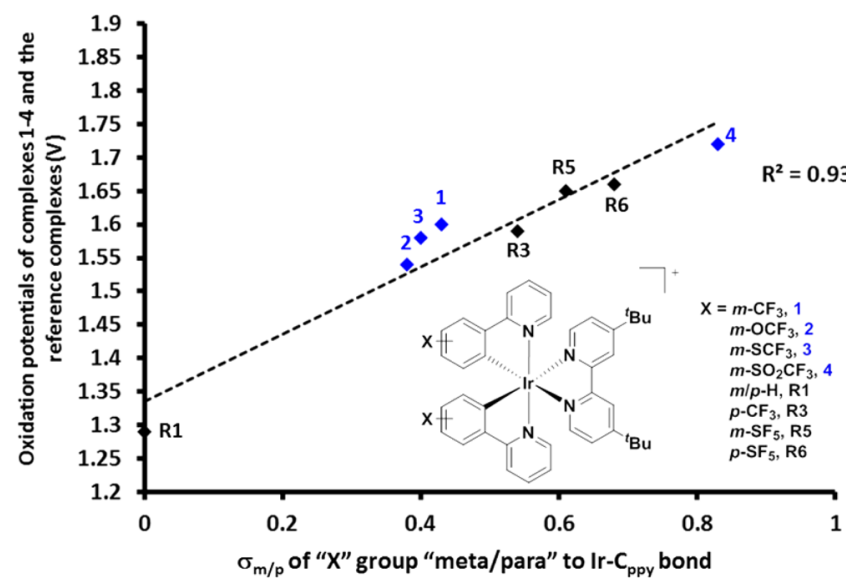

Figure 4. Plot of Hammett constant $(\sigma)$ of the EWG (or X) group with the corresponding oxidation potentials of the complexes 1-4 and benchmark complexes R1, R3, R5, and R6.

is prone to undergo irreversible reduction. This second irreversible reduction of 4 , presumably localized on the $-\mathrm{SO}_{2} \mathrm{CF}_{3}$ group of $\mathbf{L} 4$ as suggested by DFT calculation, occurs very closely to the first quasireversible reduction, thus contributing to the overall irreversible nature of the reduction profile of complex 4. Such behavior had previously been observed for $\mathrm{SF}_{5}$-containing cationic iridium complexes. ${ }^{26}$ The trend in the redox gap $\left(\Delta E_{\text {redox }}\right)$ of complexes $\mathbf{1 - 4}$, along with that of R1, satisfactorily matches the trend in the calculated HOMO-LUMO energy differences (Table 1). The EWGs found on the $\mathrm{C}^{\wedge} \mathrm{N}$ ligands stabilize both the HOMO and the LUMO though the former is affected to a much more appreciable degree than the latter. Thus, the electronics of 1-4 are essentially HOMO-modulated (Figure 3). Due to the strong electron-withdrawing nature of the $-\mathrm{SO}_{2} \mathrm{CF}_{3}$ group, the 


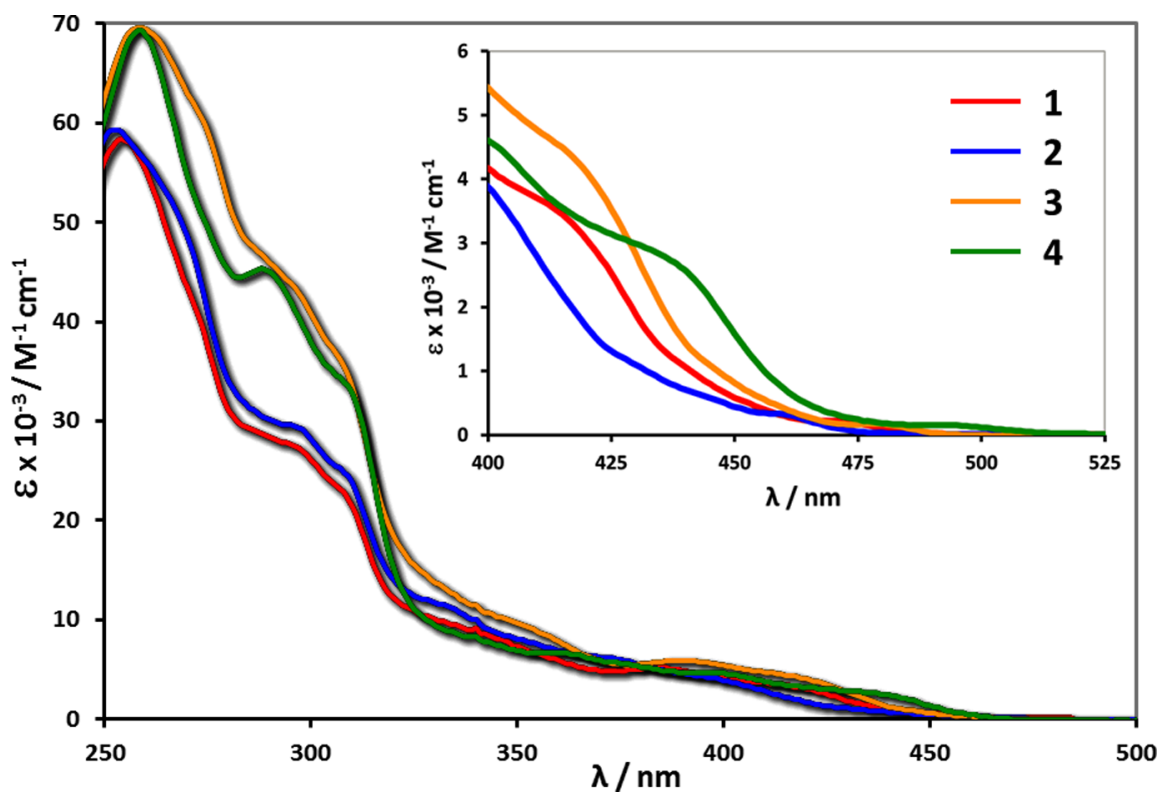

Figure 5. UV-vis spectra of complexes 1, 2, 3, and 4 recorded in $\mathrm{MeCN}$ at $298 \mathrm{~K}$ (inset shows magnified spectra from 400 to $525 \mathrm{~nm}$ ).

Table 2. Relevant Photophysical Data for Complexes 1-4

\begin{tabular}{|c|c|c|c|c|c|c|c|}
\hline \multirow[b]{3}{*}{ compd } & \multirow[b]{2}{*}{ absorption (in $\mathrm{MeCN}$ ) } & \multicolumn{6}{|c|}{ emission $^{a}$} \\
\hline & & \multicolumn{2}{|c|}{$\lambda_{\mathrm{em}} / \mathrm{nm}$} & \multirow[b]{2}{*}{$\tau_{\mathrm{e}} / \mu \mathrm{s}$} & \multirow[b]{2}{*}{$\Phi_{\mathrm{PL}} / \%$} & \multirow[b]{2}{*}{$10^{-5} \times k_{\mathrm{r}} / \mathrm{s}^{-1}$} & \multirow[b]{2}{*}{$10^{-5} \times k_{\mathrm{nr}} / \mathrm{s}^{-1}$} \\
\hline & $\lambda_{\mathrm{abs}} / \mathrm{nm}\left(\varepsilon \times 10^{-3} / \mathrm{M}^{-1} \mathrm{~cm}^{-1}\right)$ & $\mathrm{MeCN}$ & DCM & & & & \\
\hline 1 & $411(3.6), 470(0.22)$ & 484,516 & $487(\mathrm{sh}), 517$ & 1.79 & 45 & 2.51 & 3.08 \\
\hline 2 & $400(3.8), 460(0.31)$ & 527 & 530 & 1.14 & 50 & 4.38 & 4.39 \\
\hline 3 & $420(4.1), 479(0.19)$ & 491,525 & 494(sh), 524 & 3.31 & 66 & 1.99 & 1.03 \\
\hline 4 & $436(2.7), 494(0.16)$ & 515,545 & 510,543 & 4.28 & 55 & 1.28 & 1.06 \\
\hline $\mathbf{R} \mathbf{1}^{b}$ & $415(4.8), 465(1.0)$ & 591 & & 0.386 & 27 & 7 & 19 \\
\hline $\mathbf{R 2}$ & $411(3.3), 465 \operatorname{sh}(0.67)^{c}$ & $602^{b}$ & & $0.275^{b}$ & $9.3^{b}$ & $3.4^{b}$ & $33^{b}$ \\
\hline $\mathbf{R} 3^{d}$ & $\sim 410,460$ & & 512 & 1.2 & 66 & & \\
\hline $\mathbf{R} 4^{e}$ & & 543 & & 1.2 & 26 & & \\
\hline $\mathbf{R 5}^{f}$ & $384(5.0)$ & 482 & 482 & 4.7 & 79 & & \\
\hline $\mathbf{R} 6^{f}$ & $368(5.2, \mathrm{sh})$ & 496 & 498 & 2.0 & 71 & & \\
\hline
\end{tabular}

${ }^{a}$ In degassed $\mathrm{MeCN}$ at room temperature. Steady-state emission spectra were also recorded in degassed DCM. Steady-state emission (in MeCN): $\lambda_{\text {exc }}=360 \mathrm{~nm}$. Time-resolved emission (in $\mathrm{MeCN}$ ): $\lambda_{\text {exc }}=378 \mathrm{~nm}$. Solution $\Phi_{\mathrm{PL}}$ values were measured using quinine sulfate as the external reference $\left(\lambda_{\text {em }}=450 \mathrm{~nm}\right.$ in MeCN, $\Phi_{\mathrm{r}}=54.6 \%$ in $0.5 \mathrm{M} \mathrm{H}_{2} \mathrm{SO}_{4}$ as found in ref 66$) .{ }^{b}$ From ref $8 .{ }^{c}$ From ref $67 .{ }^{d}$ Photophysical data in degassed DCM solution $\left(\Phi_{\mathrm{PL}}\right.$ was determined using quinine hemisulfate salt monohydrate $\left(\Phi_{\mathrm{ref}}=54.6 \%\right.$ in $\left.0.5 \mathrm{M} \mathrm{H}_{2} \mathrm{SO}_{4}\right)$ as standard) from ref $58 .{ }^{e}$ Photophysical data in degassed $\mathrm{MeCN}$ solution $\left(\Phi_{\mathrm{PL}}\right.$ was determined using $\left[\operatorname{Ir}(\mathrm{ppy})_{2}(\mathrm{bpy})\right] \mathrm{Cl}\left(\Phi_{\mathrm{ref}}=6.22 \%\right)$ as standard) from ref $60 .{ }^{f}$ From ref 26.

first reduction of 4 is anodically shifted by between 20 and 50 $\mathrm{mV}$ compared to those of $\mathbf{1}-\mathbf{3}$.

The reduction potential of 1 , where the $-\mathrm{CF}_{3}$ substituent is positioned meta to the $\mathrm{Ir}-\mathrm{C}_{\mathrm{ppy}}$ bond, is found to be anodically shifted by $\sim 30 \mathrm{mV}$ compared to those of $\mathbf{R} 3$, where the $-\mathrm{CF}_{3}$ substituent is positioned para to the $\mathrm{Ir}-\mathrm{C}_{\mathrm{ppy}}$ bond. In a comparison of both the oxidation and reduction potentials, the result demonstrates that $\mathbf{1}$ is harder to oxidize, but easier to reduce compared to R3. This fact does not follow the trend of Hammett constants $(\sigma)$ of the electron-withdrawing $-\mathrm{CF}_{3}$ substituent when regiospecifically positioned $\left(\sigma_{\mathrm{m}}=0.43, \sigma_{\mathrm{p}}=\right.$ $0.54)^{42}$

Photophysical Properties. The UV-vis absorption properties of complexes $\mathbf{1 - 4}$ have been investigated in $\mathrm{MeCN}$ solution at room temperature and the respective spectra are shown in Figure 5; the data are summarized in Table 2 and Table S4. Overlays of each of the experimentally observed UV-vis absorption spectra of the complexes with their predicted transitions at different wavelengths as obtained by singlet TD-DFT calculations are shown in Figure S46. The absorption spectra of all the complexes are characterized by two intense bands between 250 and $300 \mathrm{~nm}$ and several lowerintensity bands beyond $300 \mathrm{~nm}$. Predominant spin-allowed singlet ${ }^{1} \pi \rightarrow \pi^{*}$ ligand-centered $\left({ }^{1} \mathrm{LC}\right)$ transitions centered both on cyclometallating and the ancillary ligands, as predicted by TD-DFT calculations of complexes 1-4 (Tables S5-S8), are observed at the highest-energy band, whereas the other intense peaks at $\sim 290 \mathrm{~nm}$ result mainly from ${ }^{1} \mathrm{LC}$ transitions and along with minor amounts of ${ }^{1} \mathrm{MLCT}$ transitions. Between 300 and $400 \mathrm{~nm}$ the electronic transitions constitute ${ }^{1} \mathrm{LC}$ and ${ }^{1}$ MLCT transitions, with varying contributions of ${ }^{1} \mathrm{MLCT}$ and singlet ligand-to-ligand transition ( ${ }^{1} \mathrm{LLCT}$ ) from one complex to another. For complexes 1, 3, and 4 the electronic transitions between $410-436 \mathrm{~nm}$ are assigned as HOMO $\rightarrow$ LUMO transitions, whereas for complex 2 the similar peak at $400 \mathrm{~nm}$ is assigned as a HOMO $\rightarrow$ LUMO +1 transition (Tables S5S8). For 2, the lowest-energy HOMO $\rightarrow$ LUMO transition is 

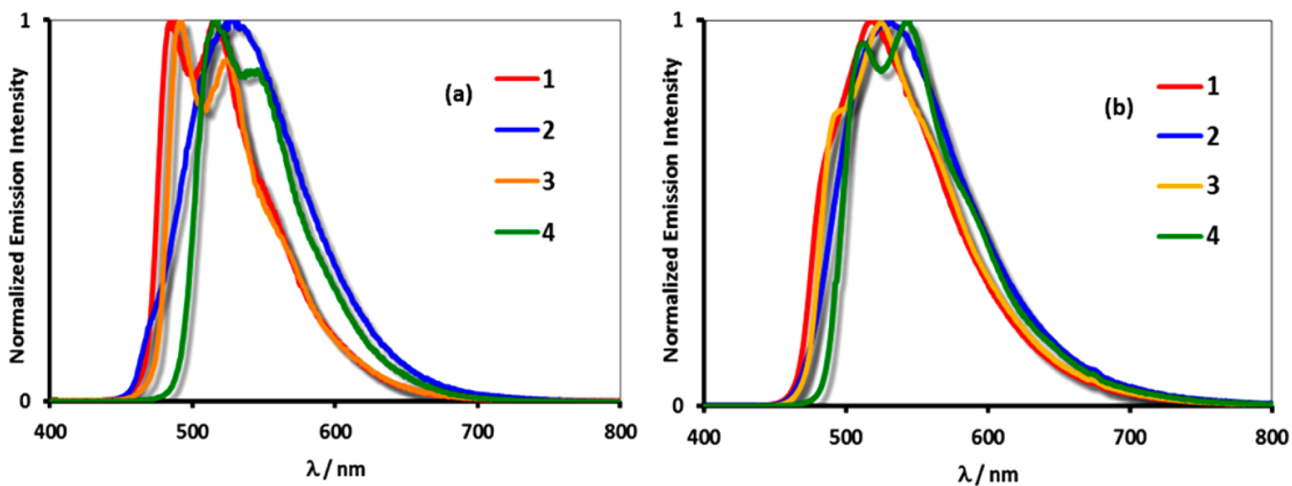

Figure 6. Normalized photoluminescence spectra of complexes 1-4 recorded in degassed (a) MeCN and (b) DCM at $298 \mathrm{~K}\left(\lambda_{\text {exc }}: 360 \mathrm{~nm}\right.$.).

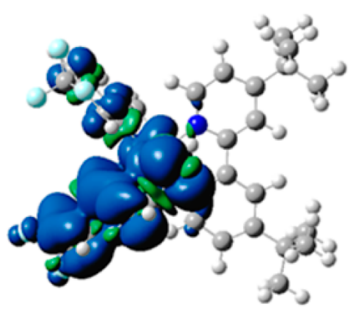

1

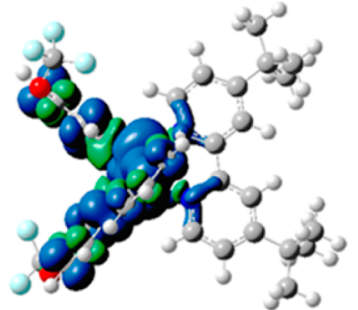

2

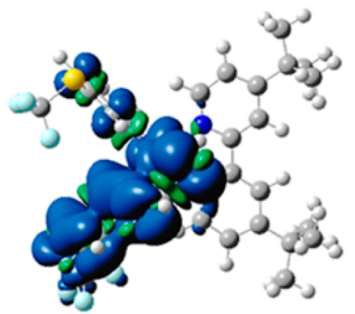

3

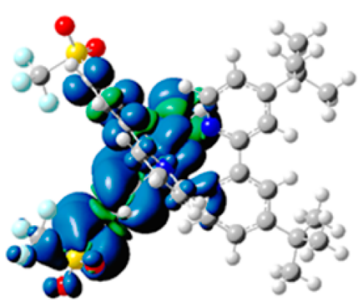

4

Figure 7. Triplet spin density distributions of complexes 1-4, obtained from DFT [(UB3LYP/SBKJC-VDZ for Ir(III)) and (6-31g** for C,H,N, $(\mathrm{O}), \mathrm{F},(\mathrm{S}))]$ with $\mathrm{CPCM}(\mathrm{MeCN})$. Contours are isovalued at 0.02 .

predicted at $452 \mathrm{~nm}$. All the complexes exhibit a shoulder band at $\lambda>450 \mathrm{~nm}$, albeit with poor molar absorptivity, which is also present in the complex R1 at $465 \mathrm{~nm} .{ }^{57}$ These hypochromic bands at lower energy are the result of poor spatial overlap between the HOMO and LUMO and are similar to those of many other cationic iridium complexes of the form $\left[\operatorname{Ir}\left(\mathrm{C}^{\wedge} \mathrm{N}\right)_{2^{-}}\right.$ $\left.\left(\mathrm{N}^{\wedge} \mathrm{N}\right)\right]^{+}$found in the literature. ${ }^{59,60}$ This spectral feature is predicted by TD-DFT calculations, ${ }^{61-64}$ and these bands are assigned to a mixture of spin-allowed and spin-forbidden charge transfer transitions ( ${ }^{1} \mathrm{MLCT},{ }^{3} \mathrm{MLCT}$, and $\left.{ }^{1} \mathrm{LLCT}\right)$ due to strong spin-orbit coupling of the Ir-metal center. Although a blue-shift in the lowest-energy absorption band is expected for complex 4 in the presence of the strongly electron-withdrawing $-\mathrm{SO}_{2} \mathrm{CF}_{3}$ group compared to those of complexes $\mathbf{1}, \mathbf{2}$, and 3 , surprisingly, a strong bathochromic shift is observed for this complex. Contrary to the DFT calculated HOMO-LUMO gap for 1-4 (Figure 3), the lowest-energy absorption maxima of these complexes are red-shifted compared to that of R1, which may suggest an additional stabilization of the LUMOs of the complexes 1-4 compared to the energy of the LUMO of complex R1 due to the strong electron-withdrawing nature of the EWGs.

Figure 6 illustrates the normalized room temperature emission spectra of 1-4 upon photoexcitation into the CT band (at $360 \mathrm{~nm}$ ) in degassed acetonitrile. Emission maxima $\left(\lambda_{\text {em }}\right)$, excited-state lifetime $\left(\tau_{\mathrm{e}}\right)$, and photoluminescence quantum yield $\left(\Phi_{\mathrm{PL}}\right)$ values along with the low-energy absorption maxima of $\mathbf{1 - 4}$ are summarized in Table 2. In $\mathrm{MeCN}$ solution, sky-blue to blue-green emission with maxima ranging from 484 to $545 \mathrm{~nm}$ is observed for 1-4 (Figure 6a). The emission intensity increases upon degassing with nitrogen, which is a hallmark of phosphorescence. In degassed dilute MeCN solution, 1, 3, and 4 exhibit structured emission that is characteristic of emission origination from a ${ }^{3} \mathrm{LC}$ state while 2 displays broad and unstructured emission, typical of mixed ${ }^{3} \mathrm{CT}$ emission. Spin-unrestricted DFT calculations point to a spin density that is more localized on the $\mathrm{C}^{\wedge} \mathrm{N}$ ligands and the central $\operatorname{Ir}(\mathrm{III})$ ion for $\mathbf{1}, \mathbf{3}$, and $\mathbf{4}$ while it is distributed to some extent to the $\mathrm{d} t$ Bubpy ligand for $\mathbf{2}$ (Figure 7). These predictions are consistent with the presence of vibronic structure in both the phosphorescence and low-energy absorbance spectra and relatively long radiative lifetimes present in 1, 3, and 4; calculations likewise predict the mixed CT character of the excited state found in 2 . . $^{2,60,65}$

Unexpectedly, 4, with the strongest $-\mathrm{SO}_{2} \mathrm{CF}_{3}$ EWG group, $\left(\sigma_{\mathrm{m}}=0.83\right)$ exhibits the most red-shifted emission maximum in $\mathrm{MeCN}$ whereas 1 with the $-\mathrm{CF}_{3}\left(\sigma_{\mathrm{m}}=0.43\right)$ exhibits the most blue-shifted emission in $\mathrm{MeCN}$. With the exception of 2, concomitant to the red-shift in the low-energy absorption maxima from 1 to 3 to 4 , the emission maxima are also redshifted (Table 2). The predicted emission maxima, $E_{\mathrm{AE}}=E\left(\mathrm{~T}_{1}\right)$ - $E\left(S_{0}\right)$, at the $T_{1}$ optimized geometries (adiabatic electronic emission) obtained by DFT calculations for complexes 1, 3, and 4 are at 541, 544, and $588 \mathrm{~nm}$ and match closely those observed experimentally and also fall in agreement with the observed trend of red-shifted emission maxima from complex 1 to 3 to 4 . By contrast, for complex 2 the predicted emission maximum at $494 \mathrm{~nm}$ is blue-shifted. (The predicted emission maxima were calculated with relative errors of $8 \%, 6 \%, 7 \%$, and $10 \%$ for 1, 2, 3, and 4, respectively, using the equation Error $=1$ $\left[\lambda_{\mathrm{em}}(298 \mathrm{~K})-E_{\mathrm{AE}}\right] / \lambda_{\mathrm{em}}(298 \mathrm{~K}) \mathrm{l}$ in $\mathrm{eV}$.) The emission profiles of the complexes in degassed DCM essentially mirror those in degassed $\mathrm{MeCN}$ with similar emission energies (Figure $6 \mathrm{~b}$ and Table 2).

Incorporation of electron-withdrawing substituents on the $\mathrm{C}^{\wedge} \mathrm{N}$ ligands promotes the expected stabilization of the frontier molecular orbitals (Figure 3) and the blue-shift in the emission observed for complexes 1-4 compared to the reference 
a)

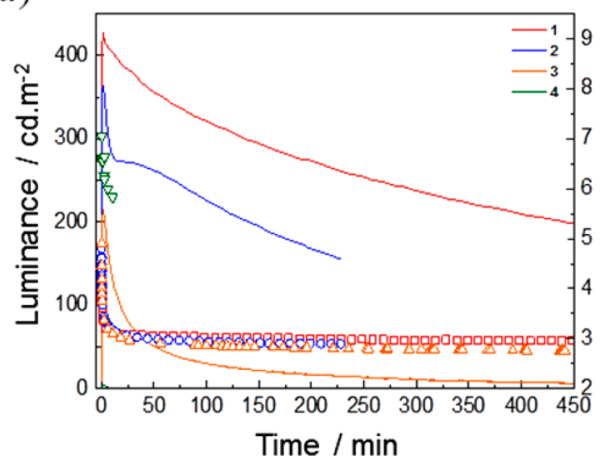

b)

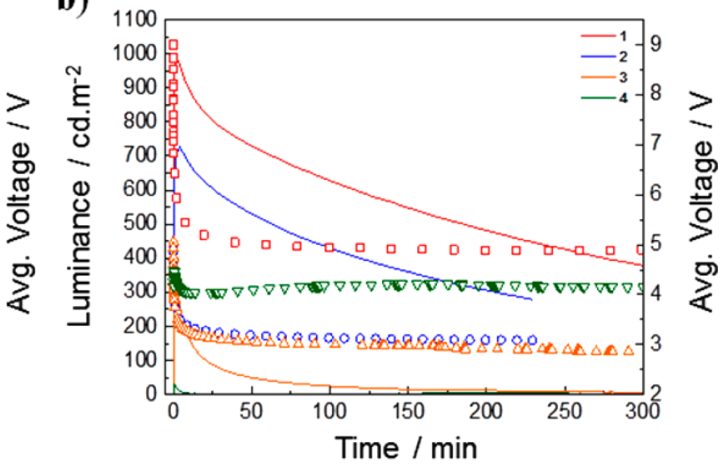

Figure 8. Luminance (solid lines) and average voltage (open symbols) vs time for LEECs 1-4. Block-wave pulsed current driving mode (frequency, $1 \mathrm{kHz}$; duty cycle, $50 \%$ ): (a) $50 \mathrm{~A} \mathrm{~m}^{-2}$, (b) $100 \mathrm{~A} \mathrm{~m}^{-2}$.

Table 3. Key Parameters of LEECs 1-4 under Block-Wave Pulsed-Current Driving Mode (Frequency, 1 kHz; Duty Cycle, 50\%) at $50 \mathrm{~A} \mathrm{~m}^{-2}$ and $100 \mathrm{~A} \mathrm{~m}^{-2}$

\begin{tabular}{|c|c|c|c|c|c|c|c|c|}
\hline compd & $\operatorname{Lum}_{\mathrm{o}}{ }^{a} / \mathrm{cd} \mathrm{m}$ & $\operatorname{Lum}_{\max } b / c d m^{-2}$ & $t_{\text {on }}^{c} / \mathrm{s}$ & $t_{\max }^{d} / \min$ & $t_{1 / 2}^{e} / \mathrm{min}$ & efficiency/cd $\mathrm{A}^{-1}$ & $\mathrm{EQE}^{f} / \%$ & $\mathrm{PCE}^{g} / \mathrm{lm} \mathrm{W}^{-1}$ \\
\hline & \multicolumn{8}{|c|}{$50 \mathrm{~A} \mathrm{~m}^{-2}$} \\
\hline 1 & 312 & 427 & $<2$ & 1.5 & 228.2 & 8.9 & 2.7 & 4.4 \\
\hline 2 & 153 & 364 & $<2$ & 1.0 & 53.7 & 7.2 & 2.3 & 3.1 \\
\hline 3 & 9 & 215 & 16 & 1.3 & 15.9 & 4.3 & 1.4 & 1.9 \\
\hline \multirow[t]{2}{*}{4} & 0 & 5 & & 1.4 & 5.7 & 0.1 & 0.03 & 0.02 \\
\hline & \multicolumn{8}{|c|}{$100 \mathrm{~A} \mathrm{~m}^{-2}$} \\
\hline 1 & 19 & 987 & 5 & 2.3 & 179.0 & 9.8 & 3.0 & 2.6 \\
\hline 2 & 88 & 726 & 5 & 4.3 & 109.3 & 7.3 & 2.3 & 3.3 \\
\hline 3 & 8 & 350 & 12 & 1.0 & 9.1 & 3.5 & 1.1 & 1.4 \\
\hline 4 & 0 & 32 & & 0.7 & 2.7 & 0.3 & 0.10 & 0.1 \\
\hline
\end{tabular}

${ }^{a}$ Initial luminance. ${ }^{b}$ Maximum luminance reached. ${ }^{c}$ Time to reach $100 \mathrm{~cd} \mathrm{~m}^{-2}$ luminance. ${ }^{d}$ Time to reach the maximum luminance. ${ }^{e}$ Time to reach one-half of the maximum luminance. ${ }^{f}$ Maximum external quantum efficiency reached. ${ }^{g}$ Maximum power conversion efficiency reached.

complexes R1 and R2 (Table 2). ${ }^{1,8}$ The observed blue-shift in emission maxima (either in $\mathrm{MeCN}$ or DCM) of reference complexes R3, R5, and R6 compared to those of 1-3 are in line with the higher Hammett parameter of the regiospecifically positioned EWGs (see Table 1 for Hammett parameters of different EWGs). The $\mathrm{F}$ atom in $\mathbf{R} \mathbf{4}$ acts as a moderate EWG $\left(m-\mathrm{F}, \sigma_{\mathrm{m}}=0.34\right)$, and thus, the emission maximum of $\mathbf{R} 4$ is red-shifted compared to those of 1-3. While the trend in $\sigma_{\mathrm{m}}$ correlates well with complexes 1-3, this paradigm does not fit with the red-shifted emission maximum of $4\left(m-\mathrm{SO}_{2} \mathrm{CF}_{3}, \sigma_{\mathrm{m}}=\right.$ 0.83) compared to the emission maxima observed for $\mathbf{R 5}$ and R6.

All the complexes are found to be bright emitters with high $\Phi_{\mathrm{PL}}$ values in the range $45-66 \%$. Time-resolved phosphorescence measurements were performed, and the decays were found to be monoexponential, indicating the presence of a single emissive species (Figure S47). The results are shown in Table 2, and the phosphorescence lifetimes are in the range 1.14-4.28 $\mu \mathrm{s}$. The observed higher $\tau_{\mathrm{e}}$ values for 3 and 4 may be attributed to the presence of increased steric shielding around the iridium in these two complexes that inhibits nonradiative intermolecular charge recombination. The calculated radiative, $k_{\mathrm{r}}$, and nonradiative, $k_{\mathrm{nr}}$, decay constants, where $\left[k_{\mathrm{r}}=\Phi_{\mathrm{PL}} / \tau_{\varepsilon}\right.$ and $\left.k_{\mathrm{nr}}=\left(k_{\mathrm{r}} / \Phi_{\mathrm{PL}}\right)-k_{\mathrm{r}}\right]$, are shown in Table 2 and fall in the ranges $(1.28-4.38) \times 10^{5}$ and $(1.06-4.39) \times 10^{5} \mathrm{~s}^{-1}$. 2,61 Among 1, 3, and 4 that exhibit greater LC emission, compounds 3 and 4 have lower $k_{\mathrm{r}}$ and much lower $k_{\mathrm{nr}}$ than compound 1, leading to higher $\Phi_{\mathrm{PL}}$ values for 3 and 4 that are supported by the decrease in nonradiative decay by about 3 times compared to that of 1 . Both the radiative and nonradiative decay rates are counterbalanced in the case of complex 2, which has more CT character in its emission.

Light-Emitting Electrochemical Cells (LEECs). Singlelayer LEECs were fabricated with complexes 1-4 acting as the emitters. The device architecture consisted of an indium tin oxide (ITO) semitransparent anode on which a thin layer of poly(3,4-ethylenedioxythiophene):polystyrenesulfonate, PEDOT:PSS, was spin-coated in order to facilitate charge injection into the emissive layer. The emissive layer consisted of a 4-to-1 molar ratio of the complex to the ionic liquid (IL) 1butyl-3-methylimidazolium hexafluorophosphate $[\mathrm{Bmim}]\left[\mathrm{PF}_{6}\right]$. The small amount of IL was added to shorten the turn-on time of the LEEC by increasing the concentration of ionic species and the ionic mobility in the active layer. ${ }^{68-70}$ The timedependence of the luminance and average voltage of the LEECs prepared with complexes 1-4 (for clarity, denoted as LEECs 1-4) as well as the electroluminescence spectra (EL) were evaluated using a pulsed-current driving mode. Pulsed-current compared to fixed current/voltage driving leads to devices with longer lifetimes and faster turn-on times $\left(t_{\text {on }}\right) .^{71}$

Figure 8 shows the luminance and operating voltage versus time of LEECs 1-4 driven at an average current density of 50 (Figure $8 \mathrm{a}$ ) or $100 \mathrm{~A} \mathrm{~m}^{-2}$ (Figure $8 \mathrm{~b}$ ). The luminance in all LEECs shows the typical behavior under pulsed-current driving: after biasing the device, the luminance increases, and once the maximum luminance is reached, the luminance starts to decay. However, the typical operating voltage behavior (a fast drop toward a steady-state low voltage level) was not observed in all LEECs. At $50 \mathrm{~A} \mathrm{~m}^{-2}$, the operating voltage of LEECs 1-3 presents a fast decrease and reaches a steady-state 
value at $2.8-3.0 \mathrm{~V}$, indicating no charge injection barrier. However, higher steady-state voltage values are required for LEEC 1 at a current density of $100 \mathrm{~A} \mathrm{~m}^{-2}$ and for LEEC 4 at a current density of $50 \mathrm{~A} \mathrm{~m}^{-2}$ that denotes an issue of a charge injection barrier during operation in these devices. Moreover, LEEC 4 at $100 \mathrm{~A} \mathrm{~m}^{-2}$ has a continuous increase of the operating voltage. An increase in driving voltage is generally associated with device degradation, yet the particular origin of the degradation mechanism is not easily identified. One possible device degradation mechanism can be related to the chemical degradation of the complex. The presence of an electrochemically unstable group in the complex could lead the complex to be electrochemically degraded under LEEC operation. Complex 4 has the strongest EWG group of the series $\left(-\mathrm{SO}_{2} \mathrm{CF}_{3}\right)$, and it is the only complex of the series that has an irreversible wave in the reduction process detected in the cyclic voltammetry (cf. Figure 2). This irreversibility in the reduction process produces an unbalanced amount of charges during LEEC operation causing poor LEEC performance. A similarly poor LEEC performance with lack of electroluminescence was previously reported by us when cationic iridium complexes incorporating strongly electron-withdrawing pentafluorosulfanyl groups $\left(-\mathrm{SF}_{5}\right)$ on the cyclometalating ligand were used in the emissive layer. ${ }^{26}$ These groups were also found to be electrochemically unstable.

For clarity, the device comparisons will be done at $50 \mathrm{~A} \mathrm{~m}^{-2}$, but similar conclusions can be extracted from the data of the respective LEECs driven at $100 \mathrm{~A} \mathrm{~m}^{-2}$. LEEC performance is summarized in Table 3. LEECs $\mathbf{1} \mathbf{- 3}$ only require a short turnon time $\left(t_{\text {on }}\right)$, here defined as the time needed to reach a luminance of $100 \mathrm{~cd} \mathrm{~m}^{-2}$. In all cases $t_{\text {on }}$ was determined to be faster than $20 \mathrm{~s}$, and the LEECs reached their maximum luminance after a few minutes. For LEEC $4 t_{\text {on }}$ could not be determined because of the low luminance levels achieved. The maximum luminance reached was $427,364,215$, and $5 \mathrm{~cd} \mathrm{~m}^{-2}$ for LEECs 1, 2, 3, and 4, respectively. The trend in device lifetime $\left(t_{1 / 2}\right)$, defined as the time to reach one-half of the maximum luminance, mirrors that observed for maximum luminance with $t_{1 / 2}$ of $228 \mathrm{~min}$ for LEEC 1, 54 and $16 \mathrm{~min}$ for LEECs 2 and 3, respectively, and 6 min for LEEC 4.

The current efficiency, external quantum efficiency (EQE), and power conversion efficiency (PCE) were also analyzed for the LEECs. LEEC 1 has the highest values of current efficiency, EQE, and PCE of the series with $8.9 \mathrm{~cd} \mathrm{~A}^{-1}, 2.7 \%$, and $4.4 \mathrm{~lm}$ $\mathrm{W}^{-1}$, respectively. However, these values are lower compared to the most efficient green-emitting $\operatorname{LEEC}\left(\lambda_{\mathrm{PL}(\mathrm{in} \mathrm{MeCN})}=512 \mathrm{~nm}\right.$, $\mathrm{CIE}=0.299,0.451)$ reported until now with $38 \mathrm{~cd} \mathrm{~A}^{-1}, 14.9 \%$, and $39.8 \mathrm{~lm} \mathrm{~W}^{-1}$ under constant voltage driving conditions. ${ }^{63}$ However, further comparison with green-emitter LEECs driven at constant voltage ${ }^{72}$ cannot be considered due to the voltage dependence of the LEECs' performance under constant voltage. LEECs 2 and 3 are less efficient than LEEC $\mathbf{1}$ with metrics of $7.2 \mathrm{~cd} \mathrm{~A}^{-1}, 2.3 \%$, and $3.1 \mathrm{~lm} \mathrm{~W}^{-1}$, and $4.3 \mathrm{~cd} \mathrm{~A}^{-1}$, $1.4 \%$, and $1.9 \mathrm{~lm} \mathrm{~W}^{-1}$, respectively. LEEC 4 has the lowest values of efficiency with $0.1 \mathrm{~cd} \mathrm{~A}^{-1}, 0.03 \%$, and $0.02 \mathrm{~lm} \mathrm{~W}^{-1}$. Considering ohmic contact, thin-film photoluminescence quantum yields of $15.9 \%, 32.6 \%, 15.7 \%$, and $20.1 \%$ for complexes 1-4, and a typical outcoupling of $20 \%$, the theoretical maximum external quantum efficiency (EQEmax) for LEECs $\mathbf{1 - 4}$ is $3.2 \%, 6.5 \%, 3.1 \%$, and $4.0 \%$, respectively, which elucidate low radiative losses for LEEC 1 and moderate losses for LEECs 2-4. Two mechanisms cause rapid radiationless deactivation. On the one hand, the formation and continuous growth of the doped zones during the LEEC operation leads to efficient quenching of the excitons. ${ }^{73,74}$ On the other hand, the quasireversible reduction for complexes 13 and the electrochemical instability of complex 4 suggest an unbalanced hole/electron carrier that leads to exciton quenching at one electrode interface. ${ }^{75}$ As mentioned before, the efficiency of the radiative process is directly related to the photoluminescence quantum yield of the material. However, here the trend observed in the efficiency of the device performance due to the different EWGs, $-\mathrm{CF}_{3}(\mathbf{1})>-\mathrm{OCF}_{3}$ (2) $>-\mathrm{SCF}_{3}(3)>-\mathrm{SO}_{2} \mathrm{CF}_{3}$ (4), cannot be related to the $\Phi_{\text {TFPL }}$ values measured in the thin-film configuration (see Table $4)$, where all complexes show moderate $\Phi_{\text {TFPL }}$ values, with $15.9 \%, 32.6 \%, 15.7 \%$, and $20.1 \%$ for complexes $1,2,3$, and 4 , respectively.

Table 4. Electroluminescence (EL) Data for LEECs 1-4 and Thin-Film Photoluminescence (TFPL) Data for Complexes 1-4

\begin{tabular}{clclc} 
compd & \multicolumn{1}{c}{$\lambda_{\text {max, } \mathrm{EL}} / \mathrm{nm}$} & $\mathrm{CIE}$ & $\lambda_{\max , \mathrm{TFPL}}{ }^{a} / \mathrm{nm}$ & $\Phi_{\mathrm{TFPL}}{ }^{a} / \%$ \\
$\mathbf{1}$ & $493(\mathrm{sh}), 556$ & $(0.37,0.55)$ & $493(\mathrm{sh}), 524$ & 15.9 \\
$\mathbf{2}$ & 566 & $(0.44,0.53)$ & 546 & 32.6 \\
$\mathbf{3}$ & $496(\mathrm{sh}), 568$ & $(0.44,0.53)$ & $498(\mathrm{sh}), 561$ & 15.7 \\
$\mathbf{4}$ & 566 & $(0.45,0.53)$ & 523,545 & 20.1 \\
${ }^{a} \lambda_{\text {exc }}=320 \mathrm{~nm}$. & & & \\
\hline
\end{tabular}

It is important to highlight that there is a detrimental effect of the $-\mathrm{CF}_{3}$ substituent position from para to the $\mathrm{Ir}-\mathrm{C}_{\mathrm{C}^{\wedge} \mathrm{N}}$ in $\mathbf{R} 3$ to the meta $\operatorname{Ir}-\mathrm{C}_{\mathrm{C}^{\wedge} \mathrm{N}}$ in $\mathbf{1}$ at both current densities, ${ }^{58}$ where the maximum luminance decreases from $852 \mathrm{~cd} \mathrm{~m}^{-2}$ (R3) to 427 $\mathrm{cd} \mathrm{m}^{-2}$ (1) and the external quantum efficiency (EQE) is reduced from $5.4 \%(\mathbf{R} 3)$ to $2.7 \%(\mathbf{1})$, both at $50 \mathrm{~A} \mathrm{~m}^{-2}$. LEEC 4 with the strongest EWG, $-\mathrm{SO}_{2} \mathrm{CF}_{3}$, installed on the $\mathrm{C}^{\wedge} \mathrm{N}$ ligands presents the lowest performance of the series, which we attribute exclusively to the electrochemical instability of this group. Through this study it has become evident that the $\mathrm{C}^{\wedge} \mathrm{N}$ ligands cannot be too electron-poor as this results in greater electrochemical irreversibility leading detrimentally to significantly poorer LEEC performance.

The electroluminescence (EL) and thin-film photoluminescence (PL) spectra are shown in Figure 9. Thin-film photoluminescence (PL) spectra and thin-film $\Phi_{\text {TFPL }}$ were measured using the device composition of the emissive layer

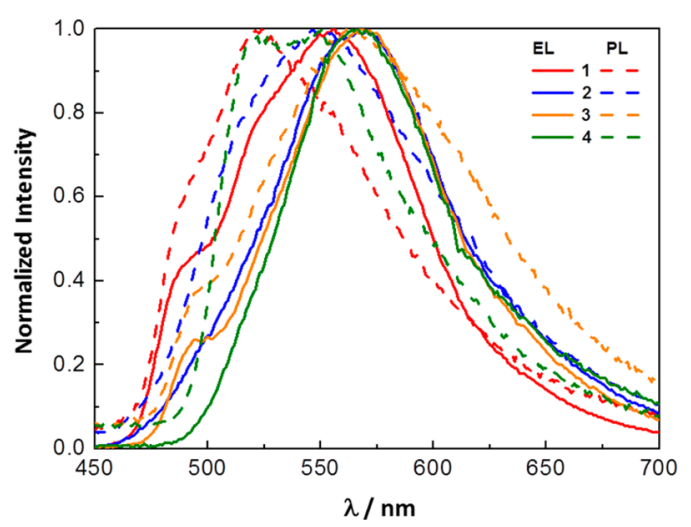

Figure 9. Electroluminescence (EL) spectra (solid line) of LEECs 14 and thin-film photoluminescence (PL) spectra (dashed line) of complexes 1-4. 
spin-coated on a quartz plate. EL and thin-film PL maximum emission wavelengths as well as $\Phi_{\mathrm{TFPL}}$ values are provided in Table 4. All devices present similar EL maxima at 556, 566, 568, and $566 \mathrm{~nm}$ for LEECs 1, 2, 3, and 4, respectively. Additionally, LEECs 1 and 3 have a high-energy shoulder at $493 \mathrm{~nm}(\mathbf{1})$ and $496 \mathrm{~nm}$ (3). The thin-film PL maxima for 1-3 are modestly blue-shifted at 524, 546, $561 \mathrm{~nm}$, respectively. Similar to their EL spectra, the thin-film PL spectra for 1 and 3 present a shoulder at $493 \mathrm{~nm}$ (1) and $498 \mathrm{~nm}$ (3). The thin-film PL spectrum for 4 presents two maximum emission peaks at 523 and $545 \mathrm{~nm}$. The structured nature of the thin-film PL spectra for 1, 3, and 4 mirrors the structured spectra observed in $\mathrm{MeCN}$ solution. Likewise, the broad and unstructured thin-film PL spectrum for $\mathbf{2}$ has the same form as that observed in $\mathrm{MeCN}$ solution. All EL maxima are red-shifted with respect to the thin-film PL maxima and with respect to the PL maxima observed in solution, but the position of the shoulder in complexes 1 and 3 remains at the same wavelength. This redshifting of the EL and thin-film PL maxima with respect to the $\mathrm{PL}$ maxima in solution is due to the aggregation in the solid state. $^{72}$

The similar EL and PL emission profiles and energies of 3 denote that the nature of the emission is produced from the same excited state. The absence of structured emission in the EL spectrum of $\mathbf{4}$ and its coincident emission energy and profile with that observed in the EL spectrum of 3 could imply an electrochemical reduction of the $-\mathrm{SO}_{2} \mathrm{CF}_{3}$ moiety to an $-\mathrm{SCF}_{3}$ group.

The Commision Internationale de l'Eclairage (CIE) coordinates were determined from the electroluminescence spectra for 1-4 (Table 4). LEEC 1 presents a blue-green emission with CIE coordinates (0.37, 0.55), and LEECs 2-4 have a green emission with similar CIE coordinates $(0.44,0,53)$ for LEEC 2, $(0.44,0,53)$ for LEEC 3, and $(0.45,0.53)$ for LEEC 4.

\section{CONCLUSIONS}

In summary, four sky-blue to blue-green emitting $\left(\lambda_{\text {em }} 484-\right.$ $525 \mathrm{~nm}$ ) cationic heteroleptic iridium(III) complexes bearing electron-withdrawing fluorocarbon ligands have been synthesized, and their optoelectronic properties were investigated. The complexes exhibit quasireversible first oxidation and reduction peaks, thereby rendering them suitable as emitters in LEECs. Surprisingly, despite containing stronger EWGs, the lowest-energy absorption maxima of $\mathbf{1 - 4}$ are more red-shifted compared to the reference complexes $\mathbf{R} \mathbf{1}$ and $\mathbf{R} \mathbf{2}$. While the trends observed in the absorption spectra of 1-4 are not in line with the predicted trend obtained from singlet TD-DFT calculations, the triplet spin density calculations are in agreement with the trend observed for the emission behavior, except for 2. However, 1-4 were shown to exhibit blue-shifted emission maxima compared to those of $\mathbf{R} \mathbf{1}$ and $\mathbf{R} \mathbf{2}$. Thus, this study demonstrates that the common design paradigm of achieving bluer emission upon introduction of increasingly stronger EWG may not always be applicable. Successful applications of these complexes in LEECs have been achieved, albeit with moderate external quantum efficiencies.

\section{EXPERIMENTAL SECTION}

General Synthetic Procedures. Commercial chemicals were used as supplied. All reactions were performed using standard Schlenk techniques under inert $\left(\mathrm{N}_{2}\right)$ atmosphere with reagent grade solvents. Flash column chromatography was performed using silica gel (Silia-P from Silicycle, $60 \AA, 40-63 \mu \mathrm{m})$. Analytical thin layer chromatography (TLC) was performed with silica plates with aluminum backings (250 $\mu \mathrm{m}$ with indicator F-254). Compounds were visualized under UV light. ${ }^{1} \mathrm{H}$ (for ligands and dimers), ${ }^{13} \mathrm{C}$, and ${ }^{19} \mathrm{~F}$ NMR spectra were recorded on a Bruker Avance spectrometer at 400,125 , and $376 \mathrm{MHz}$, respectively. ${ }^{1} \mathrm{H}$ NMR spectra for charged complexes were recorded on a Bruker Avance spectrometer at $500 \mathrm{MHz}$. The following abbreviations have been used for multiplicity assignments: "s" for singlet, "d" for doublet, " $t$ " for triplet, " $m$ " for multiplet, and "br" for broad. Deuterated dimethyl sulfoxide (DMSO- $d_{6}$ ) and deuterated dichloromethane $\left(\mathrm{CD}_{2} \mathrm{Cl}_{2}\right)$ were used as the solvents of record. ${ }^{1} \mathrm{H}$ NMR spectra were referenced to the solvent peak. Melting points (Mp's) were recorded using open-ended capillaries on an Electrothermal melting point apparatus and are uncorrected. High-resolution mass spectra were recorded at the EPSRC UK National Mass Spectrometry Facility at Swansea University on a quadrupole time-offlight (ESI-Q-TOF), model ABSciex 5600 Triple TOF, in positive electrospray ionization mode, and spectra were recorded using sodium formate solution as the calibrant. Elemental analyses were performed by Mr. Stephen Boyer, London Metropolitan University.

Syntheses of Ligands: L1-L4. 2-(4-(Trifluoromethyl)phenyl)pyridine (L1). The synthesis is a modification to that previously reported. $^{51}$ 4-Bromotrifluoromethylbenzene $(1.2 \mathrm{~g}, 5.3 \mathrm{mmol}, 1.18$ equiv), 2-(tri- $n$-butylstannyl)pyridine (85-95\%; $1.66 \mathrm{~g}, 4.5 \mathrm{mmol}, 1$ equiv), and $\left[\mathrm{Pd}\left(\mathrm{PPh}_{3}\right)_{4}\right](0.23 \mathrm{~g}, 2 \mathrm{~mol} \%$, catalyst $)$ were stirred in dry degassed toluene at $120{ }^{\circ} \mathrm{C}$ for $48 \mathrm{~h}$ to give a yellow solution. The product was purified by column chromatography twice (the reaction mixture was loaded on the column directly): first on a fine mixture of silica and $\mathrm{K}_{2} \mathrm{CO}_{3}(1.5 \mathrm{~g}$, anhydrous) to remove tin byproducts, and then just on silica $(20 \mathrm{~g})$. The elution was performed with hexane/ dichloromethane $(2 / 1$ to $1.5 / 1 \mathrm{v} / \mathrm{v})$ to afford the compound as a white crystalline solid. Yield: $0.56 \mathrm{~g}, 56 \% .{ }^{1} \mathrm{H}$ NMR $(400 \mathrm{MHz}$, DMSO- $\left.d_{6}\right) \delta(\mathrm{ppm}): 8.73(\mathrm{ddd}, J=4.79,1.80,0.94 \mathrm{~Hz}, 1 \mathrm{H}), 8.31(\mathrm{dd}$, $J=8.90,0.86 \mathrm{~Hz}, 2 \mathrm{H}), 8.08(\mathrm{dt}, J=8.04,1.03 \mathrm{~Hz}, 1 \mathrm{H}), 7.92-7.98(\mathrm{~m}$, $1 \mathrm{H}), 7.86(\mathrm{dd}, J=8.81,0.77 \mathrm{~Hz}, 2 \mathrm{H}), 7.45$ (ddd, $J=7.48,4.75,1.11$ $\mathrm{Hz}, 1 \mathrm{H}) .{ }^{19} \mathrm{~F}\left\{{ }^{1} \mathrm{H}\right\}$ NMR (376 MHz, DMSO- $\left.d_{6}\right) \delta(\mathrm{ppm}):-61.03$. The characterization matches that previously reported.

2-(4-(Trifluoromethoxy)phenyl)pyridine (L2). 1-Bromo-4(trifluoromethoxy)benzene $(1.27 \mathrm{~g}, 5.3 \mathrm{mmol}), 2$-(tri- $n$-butylstannyl)pyridine (85-95\%; $1.53 \mathrm{~g}, 4.2 \mathrm{mmol})$, and $\left[\mathrm{Pd}\left(\mathrm{PPh}_{3}\right)_{4}\right](0.21 \mathrm{~g}, 1.82$ mol \%) were stirred in dry degassed toluene at $120^{\circ} \mathrm{C}$ for $48 \mathrm{~h}$ to give yellow solution. The product was purified by column chromatography twice (the reaction mixture was loaded on the column directly): first on a fine mixture of silica and $\mathrm{K}_{2} \mathrm{CO}_{3}(1.5 \mathrm{~g})$ to remove tin byproducts, and then just on silica $(20 \mathrm{~g})$. The elution was performed with hexane/dichloromethane ( $2 / 1$ by volume) to afford the compound as a white crystalline solid. Yield: $0.8 \mathrm{~g}, 80 \% . R_{\mathrm{f}}: 0.28$ (1:1, v/v dichloromethane/hexanes on silica). Mp: $52-54{ }^{\circ} \mathrm{C} .{ }^{1} \mathrm{H}$ NMR (400 MHz, DMSO- $\left.d_{6}\right) \delta(\mathrm{ppm}): 8.67-8.70(\mathrm{~m}, 1 \mathrm{H}), 8.19-8.24$ $(\mathrm{m}, 2 \mathrm{H}), 8.01(\mathrm{dt}, J=8.04,1.03 \mathrm{~Hz}, 1 \mathrm{H}), 7.89-7.94(\mathrm{~m}, 1 \mathrm{H}), 7.46-$ $7.50(\mathrm{~m}, 2 \mathrm{H}), 7.39$ (ddd, $J=7.44,4.79,1.11 \mathrm{~Hz}, 1 \mathrm{H}) .{ }^{13} \mathrm{C}$ NMR $(125$ MHz, DMSO- $\left.d_{6}\right) \delta$ (ppm): 154.56, 149.67, 148.97, 137.87, 137.44, $128.49,123.17,123.02,121.19,120.47,119.09$, and $117.05 .{ }^{19} \mathrm{~F}\left\{{ }^{1} \mathrm{H}\right\}$ NMR (376 MHz, DMSO- $\left.d_{6}\right) \delta(\mathrm{ppm}):-56.67$. HR NSI ${ }^{+} \mathrm{MS}:[\mathrm{M}+$ $\mathrm{H}]^{+}$calcd $240.0631\left(\left[\mathrm{C}_{12} \mathrm{H}_{9} \mathrm{~F}_{3} \mathrm{NO}\right]^{+}\right)$; found 240.0632. Anal. Calcd $\left(\mathrm{C}_{12} \mathrm{H}_{8} \mathrm{~F}_{3} \mathrm{NO}\right): \mathrm{C}, 60.26 ; \mathrm{H}, 3.37$; N, 5.86\%. Found: $\mathrm{C}, 60.38 ; \mathrm{H}, 3.26$; $\mathrm{N}, 5.88 \%$. The characterization matches that previously reported. ${ }^{51}$

2-(4-((Trifluoromethyl)thio)phenyl)pyridine (L3). 4-Bromophenyltrifluoromethyl sulfide $(1.22 \mathrm{~g}, 4.719 \mathrm{mmol}), 2$-(tri- $n$-butylstannyl)pyridine (85-95\%; $1.43 \mathrm{~g}, 3.9 \mathrm{mmol})$, and $\left[\mathrm{Pd}\left(\mathrm{PPh}_{3}\right)_{4}\right](0.22 \mathrm{~g}, 1.90$ $\mathrm{mol} \%)$ were stirred in dry degassed toluene $(15 \mathrm{~mL})$ at $120{ }^{\circ} \mathrm{C}$ for 48 $\mathrm{h}$ to give yellow solution. The product was purified by column chromatography twice (the reaction mixture was loaded on the column directly): first on a fine mixture of silica $(15 \mathrm{~g})$ and $\mathrm{K}_{2} \mathrm{CO}_{3}$ ( $1.5 \mathrm{~g}$, anhydrous) to remove tin byproducts, and then just on silica $(20 \mathrm{~g})$. The elution was performed with hexane/dichloromethane $(2 / 1$ by volume) to afford the compound as a white crystalline solid. Yield: $0.76 \mathrm{~g}, 77 \%$. $R_{\mathrm{f}}: 0.34$ (1:1, v/v dichloromethane/hexanes on silica). Mp: $64-66{ }^{\circ} \mathrm{C} .{ }^{1} \mathrm{H}$ NMR $\left(400 \mathrm{MHz}\right.$, DMSO- $\left.d_{6}\right) \delta$ (ppm): 8.72 (ddd, $J=4.7,1.8,0.9 \mathrm{~Hz}, 1 \mathrm{H}), 8.27-8.21(\mathrm{~m}, 2 \mathrm{H}), 8.06(\mathrm{dt}, J=8.0,1.0 \mathrm{~Hz}$, 
$1 \mathrm{H}), 7.94(\mathrm{td}, J=7.8,1.8 \mathrm{~Hz}, 1 \mathrm{H}), 7.86-7.81(\mathrm{~m}, 2 \mathrm{H}), 7.43$ (ddd, $J=$ 7.4, 4.7, $1.1 \mathrm{~Hz}, 1 \mathrm{H}) .{ }^{13} \mathrm{C}$ NMR $\left(125 \mathrm{MHz}\right.$, DMSO- $\left.d_{6}\right) \delta$ (ppm): $154.42,149.80,141.45,137.52,136.49,130.85,128.40,127.92,125.96$, 123.59, 123.51, and 120.90. ${ }^{19} \mathrm{~F}\left\{{ }^{1} \mathrm{H}\right\}$ NMR (376 MHz, DMSO-d $\left.d_{6}\right) \delta$ (ppm): -41.9. HR APCI MS: $[\mathrm{M}+\mathrm{H}]^{+}$calcd 256.0402 $\left(\left[\mathrm{C}_{12} \mathrm{H}_{9} \mathrm{~F}_{3} \mathrm{NS}\right]^{+}\right)$; found 256.0402. Anal. Calcd $\left(\mathrm{C}_{12} \mathrm{H}_{8} \mathrm{~F}_{3} \mathrm{NS}\right)$ : C, 56.47; H, 3.16; N, 5.49\%. Found: C, 56.40; H, 3.00; N, 5.61\%.

2-(4-((Trifluoromethyl)sulfonyl)phenyl)pyridine (L4). The reaction was performed under nitrogen. 1-Bromo-4-[(trifluoromethyl)sulfonyl]benzene (1 g, $3.5 \mathrm{mmol}$, excess), 2-(tri- $n$-butylstannyl)pyridine (85-95\%; $1.2 \mathrm{~g}, 3.3 \mathrm{mmol})$, and $\left[\mathrm{Pd}\left(\mathrm{PPh}_{3}\right)_{4}\right](0.18 \mathrm{~g}, 1.56$ mol \%, catalyst) were stirred in dry degassed toluene $(10 \mathrm{~mL})$ at 120 ${ }^{\circ} \mathrm{C}$ for $24 \mathrm{~h}$ to give orange solution. The product was purified by column chromatography twice (the reaction mixture was loaded on the column directly): first on a fine mixture of silica $(15 \mathrm{~g})$ and $\mathrm{K}_{2} \mathrm{CO}_{3}$ (1.5 $\mathrm{g}$, anhydrous) to remove tin byproducts, and then just on silica $(20 \mathrm{~g})$. The elution was performed with hexane/dichloromethane $(2 / 1$ to $1 / 1$ by volume). The impurities closely precede and follow the product. One of the preceding impurities coelutes with the product and can be removed by recrystallization using the following protocol. The crude product was dissolved in dichloromethane $(10 \mathrm{~mL})$. Ethanol $(10 \mathrm{~mL})$ was added to this solution. Dichloromethane was rotor-evaporated to give a suspension of the impurity in ethanol. The mixture was allowed to settle and crystallize at room temperature overnight. The suspension was filtered. The solid was mainly the impurity. The filtrate was evaporated to give sufficiently pure product as a white crystalline solid to be used in the next step. We note that recrystallization from dichloromethane/hexane in the same manner does not separate the impurity from the product. Yield: $0.52 \mathrm{~g}, 55 \%$. $R_{\mathrm{f}}: 0.20$ (1:1, v/v dichloromethane/hexanes on silica). Mp: $71-73{ }^{\circ} \mathrm{C}$. ${ }^{1} \mathrm{H}$ NMR (400 MHz, DMSO- $\left.d_{6}\right) \delta(\mathrm{ppm}): 8.78$ (ddd, $J=4.8,1.8,1.0$ $\mathrm{Hz}, 1 \mathrm{H}), 8.57-8.51(\mathrm{~m}, 2 \mathrm{H}), 8.28-8.23(\mathrm{~m}, 2 \mathrm{H}), 8.19(\mathrm{dt}, J=8.0,1.0$ $\mathrm{Hz}, 1 \mathrm{H}), 8.01(\mathrm{td}, J=7.7,1.8 \mathrm{~Hz}, 1 \mathrm{H}), 7.52(\mathrm{ddd}, J=7.6,4.8,1.1 \mathrm{~Hz}$, $1 \mathrm{H}) .{ }^{13} \mathrm{C}$ NMR (125 MHz, DMSO-d $\left.d_{6}\right) \delta$ (ppm): 153.18, 150.13, 146.99, 137.83, 131.35, 129.26, 128.51, 124.57, 121.95, 120.75, 118.16, and 115.57. ${ }^{19} \mathrm{~F}\left\{{ }^{1} \mathrm{H}\right\}$ NMR (376 MHz, DMSO- $\left.d_{6}\right) \delta(\mathrm{ppm}):-78.5$. HR NSI ${ }^{+}$MS: $[\mathrm{M}+\mathrm{H}]^{+}$calcd 288.0301 $\left(\left[\mathrm{C}_{12} \mathrm{H}_{9} \mathrm{~F}_{3} \mathrm{NO}_{2} \mathrm{~S}\right]^{+}\right)$; found 288.0301. Anal. Calcd $\left(\mathrm{C}_{12} \mathrm{H}_{8} \mathrm{~F}_{3} \mathrm{NO}_{2} \mathrm{~S}\right)$ : C, 50.18; H, 2.81; N, $4.88 \%$. Found: C, 50.30; H, 2.72; N, 4.85\%.

Syntheses of Precursor Ir-Dimers of General Molecular Formula $\left[\operatorname{Ir}(\mathrm{C} \wedge \mathrm{N})_{2}(\mu-\mathrm{CI})\right]_{2}:$ D-L1-D-L4. Tetrakis $[2-(4-$ (trifluoromethyl)phenyl)pyridinato- $N, \mathrm{C}^{2} \mathrm{l}$-bis( $\mu$-chloro)diiridium(III) $\left[\operatorname{lr}(L 1)_{2}(\mu-C l)\right]_{2}(D-L 1)$. IrCl ${ }_{3} \cdot 3 \mathrm{H}_{2} \mathrm{O}(142 \mathrm{mg}, 0.40 \mathrm{mmol}$; iridium(III) chloride hydrate) was dissolved in a degassed mixture of 2ethoxyethanol $(6 \mathrm{~mL})$ and water $(2 \mathrm{~mL})$ at $70^{\circ} \mathrm{C}$ (bath temperature). Ligand L1 (203 mg, $0.91 \mathrm{mmol})$ was added as a solid. The mixture was stirred at $120{ }^{\circ} \mathrm{C}$ (bath temperature) for $24 \mathrm{~h}$ to give a pale orange solution. The solution was cooled to room temperature. Water $(5 \mathrm{~mL})$ was added dropwise to give a precipitate. The solid was filtered and washed with small volumes of ethanol/water $(1 / 1 \mathrm{v} / \mathrm{v})$ and with a large volume of hexane. The solid was dried under vacuum to afford the compound as a yellow solid. The product was used as a reagent for the next step without further purification. Yield: $0.205 \mathrm{~g}, 76 \% .{ }^{1} \mathrm{H}$ NMR (400 MHz, $\left.\mathrm{CD}_{2} \mathrm{Cl}_{2}\right) \delta(\mathrm{ppm}): 9.16-9.22(\mathrm{~m}, 1 \mathrm{H}), 8.05$ (d, $J=$ $7.87 \mathrm{~Hz}, 1 \mathrm{H}), 7.90-7.96(\mathrm{~m}, 1 \mathrm{H}), 7.68(\mathrm{~d}, J=8.04 \mathrm{~Hz}, 1 \mathrm{H}), 7.06-$ $7.11(\mathrm{~m}, 1 \mathrm{H}), 6.97(\mathrm{ddd} J=7.44,5.82,1.45 \mathrm{~Hz}, 1 \mathrm{H}), 6.08(\mathrm{~d}, J=$ $1.20 \mathrm{~Hz}, 1 \mathrm{H}) .{ }^{19} \mathrm{~F}\left\{{ }^{1} \mathrm{H}\right\}$ NMR $\left(376 \mathrm{MHz}, \mathrm{CD}_{2} \mathrm{Cl}_{2}\right) \delta(\mathrm{ppm}):-63.26$. The characterization matches to that previously reported. ${ }^{51}$

Tetrakis[2-(4-(trifluoromethoxy)phenyl)pyridinato- $\left.N, \mathrm{C}^{2 \prime}\right]$-bis $(\mu$ chloro)diiridium(III), $\left[\operatorname{Ir}(\mathrm{L2})_{2}(\mu-\mathrm{Cl})\right]_{2}(\mathrm{D}-\mathrm{L} 2)$. $[\mathrm{Ir}(\mathrm{COD}) \mathrm{Cl}]_{2}(250 \mathrm{mg}$, $0.37 \mathrm{mmol}$ ) and ligand $\mathbf{L 2}(375 \mathrm{mg}, 1.57 \mathrm{mmol})$ were stirred in degassed 2-ethoxyethanol $(4 \mathrm{~mL})$ at $130{ }^{\circ} \mathrm{C}$ (bath temperature) for 5 $\mathrm{h}$. The mixture briefly turned black on mixing and heating, but became a dark orange solution by the end of the reaction. The solution was cooled to room temperature. Water $(4 \mathrm{~mL})$ was added dropwise to give a precipitate. The solid was filtered and washed with ethanol/ water $(1 / 1 \mathrm{v} / \mathrm{v})$ and hexane. The solid was dried under vacuum to afford the compound as a yellow solid. The product was used as a reagent for the next step without further purification. Yield: $0.377 \mathrm{~g}$, 72\%. ${ }^{1} \mathrm{H}$ NMR (400 MHz, $\left.\mathrm{CD}_{2} \mathrm{Cl}_{2}\right) \delta(\mathrm{ppm})$ : 9.12-9.17 (m, $\left.1 \mathrm{H}\right)$, $7.95(\mathrm{~d}, J=7.53 \mathrm{~Hz}, 1 \mathrm{H}), 7.87(\mathrm{td}, J=7.74,1.63 \mathrm{~Hz}, 1 \mathrm{H}), 7.61(\mathrm{~d}, J$ $=8.55 \mathrm{~Hz}, 1 \mathrm{H}), 6.89$ (ddd, $J=7.36,5.82,1.54 \mathrm{~Hz}, 1 \mathrm{H}), 6.69-6.74$ $(\mathrm{m}, 1 \mathrm{H}), 5.64(\mathrm{dd}, J=2.31,1.11 \mathrm{~Hz}, 1 \mathrm{H}) .{ }^{19} \mathrm{~F}\left\{{ }^{1} \mathrm{H}\right\} \mathrm{NMR}(376 \mathrm{MHz}$, $\left.\mathrm{CD}_{2} \mathrm{Cl}_{2}\right) \delta(\mathrm{ppm}):-57.74$. The characterization matches that previously reported. ${ }^{51}$

Tetrakis[2-(4-((trifluoromethyl)thio)phenyl)pyridinato- $N, \mathrm{C}^{2}$ ] $]$-bis( $\mu$-chloro)diiridium(III), $\left[\operatorname{Ir}(\mathrm{LB})_{2}(\mu \text {-Cl) }]_{2}\left(\mathrm{D}\right.\right.$-L3). $[\operatorname{Ir}(\mathrm{COD}) \mathrm{Cl}]_{2}(250$ $\mathrm{mg}, 0.37 \mathrm{mmol})$ and ligand $\mathrm{L3}(403 \mathrm{mg}, 1.58 \mathrm{mmol})$ were stirred in degassed 2-ethoxyethanol $(4 \mathrm{~mL})$ at $130{ }^{\circ} \mathrm{C}$ (bath temperature) for 5 h. The mixture briefly turned black on mixing and heating but became a pale red solution by the end of the reaction. The solution was cooled to room temperature. Water $(4 \mathrm{~mL})$ was added dropwise to give a precipitate. The solid was filtered and washed with ethanol/water $(1 / 1$ by volume) and hexane. The solid was dried under vacuum to afford the compound as a yellow-orange solid. The product was used as a reagent for the next step without further purification. Yield: $0.498 \mathrm{~g}$, 91\%. ${ }^{1} \mathrm{H}$ NMR ( $400 \mathrm{MHz}, \mathrm{CD}_{2} \mathrm{Cl}_{2}$ ) $\delta$ (ppm): 9.19 (ddd, $J=5.8,1.6$, $0.8 \mathrm{~Hz}, 4 \mathrm{H}$ ), 8.02 (ddd, $J=8.3,1.4,0.7 \mathrm{~Hz}, 4 \mathrm{H}), 7.90$ (ddd, $J=9.0$, $7.5,1.6 \mathrm{~Hz}, 4 \mathrm{H}), 7.61(\mathrm{~d}, J=8.1 \mathrm{~Hz}, 4 \mathrm{H}), 7.11(\mathrm{dd}, J=8.1,1.8 \mathrm{~Hz}$, $4 \mathrm{H}), 6.93(\mathrm{ddd}, J=7.4,5.8,1.4 \mathrm{~Hz}, 4 \mathrm{H}), 6.09(\mathrm{~d}, J=1.2 \mathrm{~Hz}, 4 \mathrm{H})$. ${ }^{19} \mathrm{~F}\left\{{ }^{1} \mathrm{H}\right\}$ NMR (376 MHz, $\left.\mathrm{CD}_{2} \mathrm{Cl}_{2}\right) \delta(\mathrm{ppm}):-42.8$.

Tetrakis[2-(4-((trifluoromethyl)sulfonyl)phenyl)pyridinato- $N, \mathrm{C}^{2}$ ] bis( $\mu$-chloro)diiridium(III), $\left[\operatorname{Ir}(L 4)_{2}(\mu \text {-Cl) }]_{2}\right.$ (D-L4). $\operatorname{IrCl}_{3} \cdot 3 \mathrm{H}_{2} \mathrm{O} \quad(220$ $\mathrm{mg}, 0.62 \mathrm{mmol}$; iridium(III) chloride hydrate) was dissolved in a degassed mixture of 2-ethoxyethanol $(6 \mathrm{~mL})$ and water $(2 \mathrm{~mL})$ at 70 ${ }^{\circ} \mathrm{C}$ (bath temperature). Ligand $\mathbf{L} 4(400 \mathrm{mg}, 1.39 \mathrm{mmol}$ ) was added as a solid. The mixture was stirred at $120^{\circ} \mathrm{C}$ (bath temperature) for $24 \mathrm{~h}$ to give a red solution. The solution was cooled to room temperature to give a red suspension. Water $(2 \mathrm{~mL})$ was added dropwise to give precipitate. The solid was filtered and washed with ethanol/water $(1 / 1$ $\mathrm{v} / \mathrm{v}$ ) and with hexane. The solid was dried under vacuum to afford the compound as an orange solid. The product was used as a reagent for the next step without further purification. Yield: $0.445 \mathrm{~g}, 90 \% .{ }^{1} \mathrm{H}$ NMR (400 MHz, $\mathrm{CD}_{2} \mathrm{Cl}_{2}$ ) $\delta$ (ppm): 9.21 (ddd, $J=5.8,1.5,0.8 \mathrm{~Hz}$, $4 \mathrm{H}), 8.19(\mathrm{~d}, J=7.7 \mathrm{~Hz}, 4 \mathrm{H}), 8.07$ (ddd, $J=9.1,7.5,1.6 \mathrm{~Hz}, 4 \mathrm{H}), 7.84$ $(\mathrm{d}, J=8.2 \mathrm{~Hz}, 4 \mathrm{H}), 7.49$ (dd, $J=8.2,1.9 \mathrm{~Hz}, 4 \mathrm{H}), 7.11$ (ddd $J=7.4$, $5.8,1.4 \mathrm{~Hz}, 4 \mathrm{H}), 6.38(\mathrm{~d}, J=1.4 \mathrm{~Hz}, 4 \mathrm{H}) .{ }^{19} \mathrm{~F}\left\{{ }^{1} \mathrm{H}\right\}$ NMR $(376 \mathrm{MHz}$, $\left.\mathrm{CD}_{2} \mathrm{Cl}_{2}\right) \delta$ (ppm): -79.4 .

Syntheses of Cationic Ir-Complexes of General Molecular Formula $\left[\operatorname{Ir}(\mathrm{C} \wedge N)_{2}(\mathrm{dtBubpy})\right]\left(\mathrm{PF}_{6}\right): \mathbf{1 - 4}$. Bis $[2-(4-$ (trifluoromethyl)phenyl)pyridinato- $\left.N, C^{2}\right]\left(4,4^{\prime}\right.$-di-tert-butyl-2, $2^{\prime}$ dipyridyl)iridium(III) hexafluorophosphate, $\left[\operatorname{Ir}(L 1)_{2}(d t B u b p y)\right]\left(P_{6}\right)$, 1. Precursor dimer complex D-L1 $(200 \mathrm{mg}, 0.15 \mathrm{mmol})$ and $4,4^{\prime}$-ditert-butyl-2,2'-bipyridine $(88 \mathrm{mg}, 0.33 \mathrm{mmol})$ were stirred in a degassed mixture of dichloromethane $(20 \mathrm{~mL})$ and methanol $(4 \mathrm{~mL})$ at $40{ }^{\circ} \mathrm{C}$ (bath temperature) for $24 \mathrm{~h}$ to give a yellow solution. The solution was evaporated. The complex was purified by column chromatography on silica $(12 \mathrm{~g})$. The elution was performed with $3 \%$ of methanol in dichloromethane to remove the impurities and with $6 \%$ of methanol in dichloromethane to give a yellow eluate of the product. The fractions were evaporated to dryness. The product was redissolved in methanol $(5 \mathrm{~mL})$, and added to a vigorously stirred aqueous solution $(30 \mathrm{~mL})$ of $\mathrm{NH}_{4} \mathrm{PF}_{6}(1.4 \mathrm{~g}, 8.6 \mathrm{mmol})$ over $30 \mathrm{~min}$ to give a precipitate of the hexafluorophosphate salt. The product was filtered and washed with water and ether/hexane $(1 / 1 \mathrm{v} / \mathrm{v})$. The product was dissolved in $2 \mathrm{~mL}$ of dichloromethane and added to 40 $\mathrm{mL}$ of vigorously stirred ether. The product separated first as oil, but then it crystallized to a solid. The product was filtered, washed with ether, and dried under vacuum to afford a yellow solid. Yield: $0.221 \mathrm{~g}$, $70 \%$. $R_{\mathrm{f}}: 0.71$ (5\% $\mathrm{MeOH}$ in dichloromethane on silica). Mp: 276$280{ }^{\circ} \mathrm{C} .{ }^{1} \mathrm{H}$ NMR $\left(500 \mathrm{MHz}, \mathrm{CD}_{2} \mathrm{Cl}_{2}\right) \delta(\mathrm{ppm}): 8.32(\mathrm{~d}, J=1.7 \mathrm{~Hz}$, $2 \mathrm{H}), 8.07(\mathrm{~d}, J=8.0 \mathrm{~Hz}, 2 \mathrm{H}), 7.91(\mathrm{dt}, J=7.6,1.5 \mathrm{~Hz}, 2 \mathrm{H}), 7.86(\mathrm{~d}, J$ $=8.2 \mathrm{~Hz}, 2 \mathrm{H}), 7.82(\mathrm{~d}, J=5.8 \mathrm{~Hz}, 2 \mathrm{H}), 7.59(\mathrm{dd}, J=5.8,0.7 \mathrm{~Hz}, 2 \mathrm{H})$, $7.47(\mathrm{dd}, J=5.9,1.9 \mathrm{~Hz}, 2 \mathrm{H}), 7.34(\mathrm{dd}, J=8.2,1.1 \mathrm{~Hz}, 2 \mathrm{H}), 7.16$ (ddd, $J=7.3,5.8,1.4 \mathrm{~Hz}, 2 \mathrm{H}), 6.46(\mathrm{~d}, J=0.8 \mathrm{~Hz}, 2 \mathrm{H}), 1.43(\mathrm{~s}, 18 \mathrm{H})$. ${ }^{13} \mathrm{C}$ NMR $\left(125 \mathrm{MHz}, \mathrm{CD}_{2} \mathrm{Cl}_{2}\right) \delta$ (ppm): 166.17, 164.60, 155.42, $150.15,149.83,149.00,147.41,138.91,131.45,131.21,127.27,125.88$, $124.87,124.72,121.34,120.93,119.88,35.69,29.94 .{ }^{19} \mathrm{~F}\left\{{ }^{1} \mathrm{H}\right\}$ NMR $\left(376 \mathrm{MHz}, \mathrm{CD}_{2} \mathrm{Cl}_{2}\right) \delta(\mathrm{ppm}):-73.3\left(\mathrm{~d}, J=713 \mathrm{~Hz}, \mathrm{PF}_{6}^{-}\right),-63.2(\mathrm{~s}$, $\left.\mathrm{CF}_{3}\right)$. HR NSI ${ }^{+} \mathrm{MS}:\left[\mathrm{M}-\mathrm{PF}_{6}\right]^{+}(100 \%)$ calcd 905.2627 
$\left(\mathrm{C}_{42} \mathrm{H}_{38} \mathrm{~N}_{4} \mathrm{~F}_{6} \mathrm{Ir}^{+}\right)$; found 905.2601. Anal. Calcd $\left(\mathrm{C}_{42} \mathrm{H}_{38} \mathrm{~N}_{4} \mathrm{~F}_{12} \mathrm{PIr}\right)$ : C, 48.05; H, 3.65; N, 5.34\%. Found: C, 48.19; H, 3.54; N, 5.35\%.

Bis[2-(4-(trifluoromethoxy)phenyl)pyridinato- $\left.N, C^{2}{ }^{\prime}\right]\left(4,4^{\prime}\right.$-di-tertbutyl-2,2'-dipyridyl)iridium(III) hexafluorophosphate, [Ir(L2) $\left.{ }_{2}(d t B u b p y)\right]\left(P F_{6}\right)$, 2. Precursor dimer complex D-L2 (200 mg, $0.14 \mathrm{mmol})$ and 4,4'-di-tert-butyl-2,2' -bupyridine $(82 \mathrm{mg}, 0.31 \mathrm{mmol})$ were stirred in a degassed mixture of dichloromethane $(20 \mathrm{~mL})$ and methanol $(4 \mathrm{~mL})$ at $40{ }^{\circ} \mathrm{C}$ (bath temperature) for $24 \mathrm{~h}$ to give a dark yellow solution. The solution was evaporated. The complex was purified by column chromatography on silica $(12 \mathrm{~g})$. The elution was performed with $3 \%$ of methanol in dichloromethane to remove the impurities and with $6 \%$ of methanol in dichloromethane to give a yellow eluate of the product. The fractions were evaporated to dryness. The product was redissolved in methanol $(4 \mathrm{~mL})$, and added to a vigorously stirred aqueous solution $(30 \mathrm{~mL})$ of $\mathrm{NH}_{4} \mathrm{PF}_{6}(1.5 \mathrm{~g}, 9.2$ $\mathrm{mmol}$ ) over $30 \mathrm{~min}$ to give a precipitate of the hexafluorophosphate salt. The product was filtered and washed with water and ether/hexane $(1 / 1 \mathrm{v} / \mathrm{v})$. The product was dissolved in $4 \mathrm{~mL}$ of dichloromethane and added to a mixture of vigorously stirred ether $(50 \mathrm{~mL})$ and hexane $(50$ $\mathrm{mL}$ ). The product separated first as oil, but then it crystallized to a solid. The product was filtered, washed with ether/hexane $(1 / 1 \mathrm{v} / \mathrm{v})$, and dried under vacuum to afford a yellow solid. Yield: $0.214 \mathrm{~g}, 71 \%$. $R_{\mathrm{f}}: 0.72\left(5 \% \mathrm{MeOH}\right.$ in dichloromethane on silica). $\mathrm{Mp}: 215-218^{\circ} \mathrm{C}$. ${ }^{1} \mathrm{H}$ NMR (500 MHz, $\left.\mathrm{CD}_{2} \mathrm{Cl}_{2}\right) \delta(\mathrm{ppm}): 8.35(\mathrm{~d}, J=1.7 \mathrm{~Hz}, 2 \mathrm{H}), 7.96$ $(\mathrm{d}, J=7.8 \mathrm{~Hz}, 2 \mathrm{H}), 7.87(\mathrm{~d}, J=5.5 \mathrm{~Hz}, 2 \mathrm{H}), 7.86(\mathrm{dt}, J=8.2,1.5 \mathrm{~Hz}$, $2 \mathrm{H}), 7.79(\mathrm{~d}, J=8.6 \mathrm{~Hz}, 2 \mathrm{H}), 7.50(\mathrm{ddd}, J=5.8,1.4,0.7 \mathrm{~Hz}, 2 \mathrm{H}), 7.48$ (dd, $J=5.9,2.0 \mathrm{~Hz}, 2 \mathrm{H}$ ), 7.08 (ddd, $J=7.4,5.8,1.4 \mathrm{~Hz}, 2 \mathrm{H}), 6.96$ (ddd, $J=8.6,2.4,1.2 \mathrm{~Hz}, 2 \mathrm{H}), 6.02(\mathrm{dd}, J=2.3,1.0 \mathrm{~Hz}, 2 \mathrm{H}), 1.43(\mathrm{~s}$, 18H). ${ }^{13} \mathrm{C}$ NMR $\left(125 \mathrm{MHz}, \mathrm{CD}_{2} \mathrm{Cl}_{2}\right) \delta$ (ppm): 166.92, 165.11, $156.00,152.72$, 151.01, 150.67, 149.20, 142.84, 139.28, 126.80, 126.37, 124.37, 122.97, 121.96, 120.84, 119.87, 114.94, 36.26, 30.53. ${ }^{19} \mathrm{~F}\left\{{ }^{1} \mathrm{H}\right\}$ NMR $\left(376 \mathrm{MHz}, \mathrm{CD}_{2} \mathrm{Cl}_{2}\right) \delta(\mathrm{ppm}):-73.4\left(\mathrm{~d}, J=713 \mathrm{~Hz}, \mathrm{PF}_{6}^{-}\right)$, $-57.6\left(\mathrm{~s}, \mathrm{OCF}_{3}\right) . \mathrm{HR} \mathrm{NSI}^{+} \mathrm{MS}:\left[\mathrm{M}-\mathrm{PF}_{6}\right]^{+}(100 \%)$ calcd 937.2525 $\left(\mathrm{C}_{42} \mathrm{H}_{38} \mathrm{~N}_{4} \mathrm{O}_{2} \mathrm{~F}_{6} \mathrm{Ir}^{+}\right)$; found 937.2495. Anal. Calcd $\left(\mathrm{C}_{42} \mathrm{H}_{38} \mathrm{~N}_{4} \mathrm{O}_{2} \mathrm{~F}_{12} \mathrm{PIr}\right): \mathrm{C}, 46.62 ; \mathrm{H}, 3.54 ; \mathrm{N}, 5.18 \%$. Found: C, 46.73; $\mathrm{H}, 3.49$; N, $5.25 \%$.

Bis[2-(4-((trifluoromethyl)thio) phenyl)pyridinato- $\left.N, C^{2}\right]\left(4,4^{\prime}-d i-\right.$ tert-butyl-2,2'-dipyridyl)iridium(III) hexafluorophosphate, [Ir$\left(\mathrm{LB}_{2}(\mathrm{dtBubpy})\right]\left(\mathrm{PF}_{6}\right)$, 3. Precursor dimer complex D-L3 (200 mg, $0.14 \mathrm{mmol})$ and 4,4'-di-tert-butyl-2,2'-bipyridine $(77 \mathrm{mg}, 0.29 \mathrm{mmol})$ were stirred in a degassed mixture of dichloromethane $(20 \mathrm{~mL})$ and methanol $(4 \mathrm{~mL})$ at $40{ }^{\circ} \mathrm{C}$ (bath temperature) for $24 \mathrm{~h}$ to give a bright yellow solution. The solution was evaporated. The complex was purified by column chromatography on silica $(12 \mathrm{~g})$. The elution was performed with $3 \%$ of methanol in dichloromethane to remove the impurities and with $6 \%$ of methanol in dichloromethane to give a yellow eluate of the product. The solution was evaporated to dryness. The product was redissolved in methanol $(4 \mathrm{~mL})$, and added to a vigorously stirred aqueous solution $(30 \mathrm{~mL})$ of $\mathrm{NH}_{4} \mathrm{PF}_{6}(1.5 \mathrm{~g}, 9.2$ $\mathrm{mmol}$ ) over $30 \mathrm{~min}$ to give a precipitate of the hexafluorophosphate salt. The solid was filtered and washed with water and ether/hexane $(1 / 1 \mathrm{v} / \mathrm{v})$. The solid was dissolved in $2.5 \mathrm{~mL}$ of dichloromethane and added to vigorously stirred ether $(40 \mathrm{~mL})$. A precipitate formed. The product was filtered, washed with ether, and dried under vacuum to afford a yellow solid. Yield: $0.222 \mathrm{~g}, 71 \%$. $R_{\mathrm{f}}: 0.71(5 \% \mathrm{MeOH}$ in dichloromethane on silica). $\mathrm{Mp}: 316-320^{\circ} \mathrm{C}$ (depends on the rate of heating). ${ }^{1} \mathrm{H}$ NMR (500 MHz, $\left.\mathrm{CD}_{2} \mathrm{Cl}_{2}\right) \delta(\mathrm{ppm}): 8.37(\mathrm{~d}, J=1.7 \mathrm{~Hz}$, $2 \mathrm{H}), 8.03(\mathrm{~d}, J=7.9 \mathrm{~Hz}, 2 \mathrm{H}), 7.89(\mathrm{dt}, J=7.6,1.5 \mathrm{~Hz}, 2 \mathrm{H}), 7.85$ (d, $J$ $=5.9 \mathrm{~Hz}, 2 \mathrm{H}), 7.77(\mathrm{~d}, J=8.2 \mathrm{~Hz}, 2 \mathrm{H}), 7.55(\mathrm{dd}, J=5.8,0.7 \mathrm{~Hz}, 2 \mathrm{H})$, $7.46(\mathrm{dd}, J=5.9,1.9 \mathrm{~Hz}, 2 \mathrm{H}), 7.35(\mathrm{dd}, J=8.1,1.7 \mathrm{~Hz}, 2 \mathrm{H}), 7.14$ (ddd, $J=7.3,5.8,1.4 \mathrm{~Hz}, 2 \mathrm{H}), 6.46(\mathrm{~d}, J=1.1 \mathrm{~Hz}, 2 \mathrm{H}), 1.43(\mathrm{~s}, 18 \mathrm{H})$. ${ }^{13} \mathrm{C}$ NMR (125 MHz, $\mathrm{CD}_{2} \mathrm{Cl}_{2}$ ) $\delta$ (ppm): 166.83, 165.16, 156.04, 151.18, 150.60, 149.39, 146.69, 139.39, 138.29, 131.57, 130.06, 127.01, $126.39,125.87,125.10,122.05,121.37,36.26,30.52 .{ }^{19} \mathrm{~F}\left\{{ }^{1} \mathrm{H}\right\}$ NMR $\left(376 \mathrm{MHz}, \mathrm{CD}_{2} \mathrm{Cl}_{2}\right) \delta(\mathrm{ppm}):-73.3\left(\mathrm{~d}, J=713 \mathrm{~Hz}, \mathrm{PF}_{6}^{-}\right),-42.5(\mathrm{~s}$, $\left.\mathrm{SCF}_{3}\right)$. HR NSI ${ }^{+} \mathrm{MS}:\left[\mathrm{M}-\mathrm{PF}_{6}\right]^{+}(100 \%)$ calcd 969.2067 $\left(\mathrm{C}_{42} \mathrm{H}_{38} \mathrm{~N}_{4} \mathrm{~F}_{6} \mathrm{~S}_{2} \mathrm{Ir}^{+}\right)$; found 969.2037. Anal. Calcd $\left(\mathrm{C}_{42} \mathrm{H}_{38} \mathrm{~N}_{4} \mathrm{~F}_{12} \mathrm{PS}_{2} \mathrm{Ir}\right)$ : C, 45.28; H, 3.44; N, 5.03\%. Found: C, 45.40; H, 3.36; N, 5.08\%.

Bis[2-(4-((trifluoromethyl)sulfonyl)phenyl)pyridinato- $\left.N, C^{2 \prime}\right]\left(4,4^{\prime}\right.$ di-tert-butyl-2,2'-dipyridyl)iridium(III) hexafluorophosphate, [Ir-
$\left.(L 4)_{2}(d t B u b p y)\right]\left(P F_{6}\right)$, 4. Precursor dimer complex D-L4 (200 mg, $0.12 \mathrm{mmol}$ ) and 4,4'-di-tert-butyl-2,2'-bipyridine $(71 \mathrm{mg}, 0.26 \mathrm{mmol})$ were stirred in a degassed mixture of dichloromethane $(20 \mathrm{~mL})$ and methanol $(4 \mathrm{~mL})$ at $40{ }^{\circ} \mathrm{C}$ (bath temperature) for $24 \mathrm{~h}$ to give a bright yellow solution. The solution was evaporated. The product was purified by column chromatography on silica $(13 \mathrm{~g})$. The elution was performed with $3 \%$ of methanol in dichloromethane to remove the impurities and with $6 \%$ of methanol in dichloromethane to give a yellow eluate of the product. The product was evaporated to dryness. The product was redissolved in methanol $(5 \mathrm{~mL})$ and added to a vigorously stirred aqueous solution $(30 \mathrm{~mL})$ of $\mathrm{NH}_{4} \mathrm{PF}_{6}(1.5 \mathrm{~g}, 9.2$ $\mathrm{mmol}$ ) over $30 \mathrm{~min}$ to give a precipitate of the hexafluorophosphate salt. The solid was filtered and washed with water and ether/hexane ( $1 / 1$ by volume). The product was dissolved in $3 \mathrm{~mL}$ of dichloromethane and added to vigorously stirred ether $(40 \mathrm{~mL})$. A precipitate formed. The product was filtered, washed with ether, and dried under vacuum to afford a yellow solid. Yield: $0.242 \mathrm{~g}, 86 \% . R_{\mathrm{f}}$ : $0.61\left(5 \% \mathrm{MeOH}\right.$ in dichloromethane on silica). $\mathrm{Mp}: 226-232{ }^{\circ} \mathrm{C}$ (depends on the rate of heating). ${ }^{1} \mathrm{H}$ NMR $\left(500 \mathrm{MHz}, \mathrm{CD}_{2} \mathrm{Cl}_{2}\right) \delta$ (ppm): 8.39 (d, $J=1.8 \mathrm{~Hz}, 2 \mathrm{H}), 8.17(\mathrm{~d}, J=7.8 \mathrm{~Hz}, 2 \mathrm{H}), 8.02(\mathrm{dt}, J=$ $7.7,1.5 \mathrm{~Hz}, 2 \mathrm{H}), 7.98(\mathrm{~d}, J=8.2 \mathrm{~Hz}, 2 \mathrm{H}), 7.82(\mathrm{~d}, J=5.8 \mathrm{~Hz}, 2 \mathrm{H})$, $7.71(\mathrm{dd}, J=8.2,1.8 \mathrm{~Hz}, 2 \mathrm{H}), 7.67(\mathrm{dd}, J=5.8,0.7 \mathrm{~Hz}, 2 \mathrm{H}), 7.48(\mathrm{dd}$, $J=5.9,2.0 \mathrm{~Hz}, 2 \mathrm{H}), 7.32(\mathrm{ddd} J=7.4,5.8,1.4 \mathrm{~Hz}, 2 \mathrm{H}), 6.71(\mathrm{~d}, J=$ $1.6 \mathrm{~Hz}, 2 \mathrm{H}), 1.44(\mathrm{~s}, 18 \mathrm{H}) .{ }^{13} \mathrm{C} \mathrm{NMR}\left(125 \mathrm{MHz}, \mathrm{CD}_{2} \mathrm{Cl}_{2}\right) \delta(\mathrm{ppm})$ : $165.70,165.21,155.96,152.58,150.81,150.62,150.19,140.20,132.53$, $131.83,126.88,126.64,125.83,125.75,122.53,121.43,118.83,36.66$, 30.45. ${ }^{19} \mathrm{~F}\left\{{ }^{1} \mathrm{H}\right\}$ NMR $\left(376 \mathrm{MHz}, \mathrm{CD}_{2} \mathrm{Cl}_{2}\right.$ ) $\delta(\mathrm{ppm}):-79.3(\mathrm{~s}$, $\left.\mathrm{SO}_{2} \mathrm{CF}_{3}\right),-73.0\left(\mathrm{~d}, J=713 \mathrm{~Hz}, \mathrm{PF}_{6}^{-}\right) . \mathrm{HR} \mathrm{NSI}^{+} \mathrm{MS}:\left[\mathrm{M}-\mathrm{PF}_{6}\right]^{+}$ $(100 \%)$ calcd $1033.1862\left(\mathrm{C}_{42} \mathrm{H}_{38} \mathrm{~N}_{4} \mathrm{O}_{4} \mathrm{~F}_{6} \mathrm{~S}_{2} \mathrm{Ir}^{+}\right)$; found 1033.1828 . Anal. Calcd $\left(\mathrm{C}_{42} \mathrm{H}_{38} \mathrm{~N}_{4} \mathrm{O}_{4} \mathrm{~F}_{12} \mathrm{PS}_{2} \mathrm{Ir}\right)$ : C, 42.82; $\mathrm{H}, 3.25 ; \mathrm{N}, 4.76 \%$. Found: C, 42.99; H, 3.19; N, 4.87\%.

X-ray Crystallography. Single crystals were grown by vapor diffusion of ether into concentrated $\mathrm{CH}_{2} \mathrm{Cl}_{2}$ solution (1 and 2) and by slow evaporation of mixed solutions of $\mathrm{CH}_{2} \mathrm{Cl}_{2} /$ heptanes (3) or $\mathrm{CH}_{2} \mathrm{Cl}_{2}$ /hexanes (4). Data were collected at $173 \mathrm{~K}$ on a Rigaku FR-X Ultrahigh Brilliance Microfocus RA generator/confocal optics and a Rigaku XtaLAB P200 system, with Mo K $\alpha$ radiation $(\lambda=0.71075 \AA)$. Intensity data were collected using $\omega$ steps accumulating area detector images spanning at least a hemisphere of reciprocal space. All data were corrected for Lorentz polarization effects, and a multiscan absorption correction was applied by using CrystalClear. ${ }^{76}$ Structures were solved by Patterson methods (PATTY) ${ }^{17}$ and refined by fullmatrix least-squares against $F^{2}$ (SHELXL-2013). ${ }^{78}$ Non-hydrogen atoms were refined anisotropically, and hydrogen atoms were refined using a riding model. All calculations were performed using the CrystalStructure interface. ${ }^{79}$

Photophysical Measurements. All samples were prepared in HPLC grade acetonitrile with varying concentrations in the order of micromolar. Absorption spectra were recorded at room temperature using a Shimadzu UV-1800 double beam spectrophotometer. Molar absorptivity determination was verified by linear least-squares fit of values obtained from at least four independent solutions at varying concentrations ranging from $8.62 \times 10^{-5}$ to $5.48 \times 10^{-6} \mathrm{M}$.

The sample solutions for the emission spectra were prepared in HPLC grade $\mathrm{MeCN}$ and degassed via three freeze-pump-thaw cycles using an in-house designed quartz cuvette. Steady-state and timeresolved emission spectra were recorded at $298 \mathrm{~K}$ using an Edinburgh Instruments F980. All samples for steady-state measurements were excited at $360 \mathrm{~nm}$. The excited-state lifetimes of the complexes were obtained by time correlated single photon counting (TCSPC) at an excitation wavelength of $378 \mathrm{~nm}$ using an Edinburgh Instruments FLS980 fluorimeter using a pulsed diode laser, and PL emission was detected at the corresponding steady-state emission maximum for each complex. The PL decays were fitted with a single exponential decay function. Emission quantum yields were determined using the optically dilute method. ${ }^{80} \mathrm{~A}$ stock solution with absorbance of ca. 0.5 was prepared, and then four dilutions were prepared with dilution factors between 2 and 20 to obtain solutions with absorbances of ca. 0.095, $0.065,0.05$, and 0.018 , respectively. The Beer-Lambert law was found to be linear at the concentrations of the solutions. The emission 
spectra were then measured after the solutions were rigorously degassed via three freeze-pump-thaw cycles prior to spectrum acquisition. For each sample, linearity between absorption and emission intensity was verified through linear regression analysis, and additional measurements were acquired until the Pearson regression factor $\left(R^{2}\right)$ for the linear fit of the data set surpassed 0.9. Individual relative quantum yield values were calculated for each solution, and the values reported represent the slope value. The equation $\Phi_{\mathrm{s}}=\Phi_{\mathrm{r}}\left(A_{\mathrm{r}} / A_{\mathrm{s}}\right)\left(I_{\mathrm{s}} / I_{\mathrm{r}}\right)\left(n_{\mathrm{s}} / n_{\mathrm{r}}\right)^{2}$ was used to calculate the relative quantum yield of each of the sample, where $\Phi_{\mathrm{r}}$ is the absolute quantum yield of the reference, $n$ is the refractive index of the solvent, $A$ is the absorbance at the excitation wavelength, and $I$ is the integrated area under the corrected emission curve. The subscripts $\mathrm{s}$ and $\mathrm{r}$ refer to the sample and reference, respectively. A solution of quinine sulfate in $0.5 \mathrm{M} \mathrm{H}_{2} \mathrm{SO}_{4}\left(\Phi_{\mathrm{r}}=54.6 \%\right)^{66}$ was used as the external reference.

Electrochemistry Measurements. Cyclic voltammetry (CV) measurements were performed on an electrochemical analyzer potentiostat model $620 \mathrm{E}$ from $\mathrm{CH}$ Instruments at a sweep rate of $100 \mathrm{mV} / \mathrm{s}$. Differential pulse voltammetry (DPV) was conducted with an increment potential of $0.004 \mathrm{~V}$ and a pulse amplitude, width, and period of $50 \mathrm{mV}, 0.05$, and $0.5 \mathrm{~s}$, respectively. Solutions for $\mathrm{CV}$ and $\mathrm{DPV}$ were prepared in $\mathrm{MeCN}$ and degassed with $\mathrm{MeCN}$-saturated nitrogen by bubbling for about $10 \mathrm{~min}$ prior to scanning. Tetra $(n-$ butyl)ammoniumhexafluorophosphate $\left(\mathrm{TBAPF}_{6}\right.$; ca. $0.1 \mathrm{M}$ in $\mathrm{MeCN}$ ) was used as the supporting electrolyte. A silver wire was used as the pseudoreference electrode; a glassy carbon electrode was used for the working electrode, and a Pt wire was used as the counter electrode. The redox potentials are reported relative to a saturated calomel electrode (SCE) electrode with a ferrocene/ferrocenium $\left(\mathrm{Fc} / \mathrm{Fc}^{+}\right)$ redox couple as an internal reference $\left(0.38 \mathrm{~V}\right.$ vs SCE) ${ }^{55}$

Experimental uncertainties are as follows: absorption maxima, \pm 2 $\mathrm{nm}$; molar absorption coefficient, $10 \%$; redox potentials, $\pm 10 \mathrm{mV}$; emission maxima, $\pm 3 \mathrm{~nm}$; emission lifetimes, $\pm 10 \%$; luminescence quantum yields, $\pm 5 \%$.

Computations. For density functional theory (DFT) and timedependent density functional theory (TD-DFT) calculations, computational details of $[1]^{+},[2]^{+},[3]^{+}$, and $[4]^{+}$are provided in the Supporting Information.

Light-Emitting Electrochemical Cells. LEECs were fabricated with complexes 1-4 in the following way. The complexes were dissolved in acetonitrile $\left(20 \mathrm{mg} \mathrm{mL}{ }^{-1}\right)$ with 4-to-1 molar ratio of the ionic liquid (IL) 1-butyl-3-methylimidazolium hexafluorophosphate $[\mathrm{Bmim}]\left[\mathrm{PF}_{6}\right]$ and filtered through syringe filters $(0.22 \mu \mathrm{m}$ pore size $)$. Prior to the deposition of the light-emitting layers, poly $(3,4-$ ethylenedioxythiophene):polystyrenesulfonate (PEDOT:PSS, Clevios P VP Al 4083) was deposited on prepatterned ITO substrates. The PEDOT:PSS layer $(80 \mathrm{~nm})$ was spin-coated at $1000 \mathrm{rpm}$ for $60 \mathrm{~s}$ and annealed at $150{ }^{\circ} \mathrm{C}$ for $15 \mathrm{~min}$. The light-emitting layer was applied by spin-coating the respective filtered solution containing the complex and the IL, using a spin-speed of $1000 \mathrm{rpm}$ for $30 \mathrm{~s}$ (100 nm). This was all performed in ambient atmosphere. After the film deposition, the layers were transferred to an inert atmosphere glovebox $(<0.1 \mathrm{ppm}$ of $\mathrm{O}_{2}$ and $\mathrm{H}_{2} \mathrm{O}, \mathrm{MBraun}$ ) and annealed at $100{ }^{\circ} \mathrm{C}$ during $1 \mathrm{~h}$. The top electrode (70 $\mathrm{nm}$ thick film of aluminum) was deposited by moving the films to a vacuum chamber integrated in the inert atmosphere glovebox. The time-dependence of the luminance and average voltage of the LEECs prepared with complexes 1-4 (for clarity, denoted as LEECs 1-4) as well as the electroluminescence (EL) spectra were evaluated using a pulsed-current driving mode. LEECs 1-4 were operated using a block-wave pulsed-current driving mode (frequency, $1 \mathrm{kHz}$; duty cycle, 50\%). The current density during the pulse was set to 100 or $200 \mathrm{~A} \mathrm{~m}^{-2}$; the average current density applied was therefore 50 or $100 \mathrm{~A} \mathrm{~m}^{-2}$, respectively.

Thin-Film Photoluminescence. The photoluminescence spectra and quantum yields of the thin films deposited on a quartz plate (1 $\mathrm{cm}^{2}$ ) were measured in air with a Hamamatsu C9920-02 Absolute PL Quantum Yield Measurement System $\left(\lambda_{\text {exc }}=320 \mathrm{~nm}\right)$. The system is made up of an excitation light source, consisting of a xenon lamp linked to a monochromator, an integration sphere, and a multichannel spectrometer.

\section{ASSOCIATED CONTENT}

\section{Supporting Information}

The Supporting Information is available free of charge on the ACS Publications website at DOI: 10.1021/acs.inorgchem.6b01602. The research data supporting this work can be accessed at: http://dx.doi.org/10.17630/1f19249d-1888417c-9766-3bfddbb1ec5a.

NMR spectra for all $\mathrm{C}^{\wedge} \mathrm{N}$ ligands, dimers, and complexes; supplementary crystal structure data for complexes 1-4; supplementary optoelectronic and DFT data (PDF)

Crystallographic details for 1-4, corresponding to CCDC 1490428-1490431 (CIF)

\section{AUTHOR INFORMATION}

\section{Corresponding Author}

*E-mail: eli.zysman-colman@st-andrews.ac.uk. Fax: +44-1334 463808. Phone: +44-1334 463826. URL: http://www.zysmancolman.com.

\section{Notes}

The authors declare no competing financial interest.

\section{ACKNOWLEDGMENTS}

We are grateful to the European Research Council (Grant 321305), the EPSRC (EP/M02105X/1), and the University of St Andrews for financial support. We thank the EPSRC UK National Mass Spectrometry Facility at Swansea University for analytical services. We thank Umicore AG for the gift of materials. We thank Dr. Nail Shavaleev for the synthesis of the ligands and complexes in this study and Dr. Etienne Baranoff for helpful discussions. The Valencian team acknowledges support from the Spanish Ministry of Economy and Competitiveness (MINECO) (Grants MAT2014-55200, CTQ2015-71154-P, and PCIN-2015-255, and Unidad de Excelencia María de Maeztu MDM-2015-0538), European Feder funds (MAT2014-55200 and CTQ2015-71154-P), and the Generalitat Valenciana (Prometeo/2016/135). C.M. thanks the MINECO for her predoctoral contract.

\section{REFERENCES}

(1) Lowry, M. S.; Bernhard, S. Synthetically Tailored Excited States: Phosphorescent, Cyclometalated Iridium(III) Complexes and Their Applications. Chem. - Eur. J. 2006, 12, 7970.

(2) Flamigni, L.; Barbieri, A.; Sabatini, C.; Ventura, B.; Barigelletti, F. Photochemistry and Photophysics of Coordination Compounds: Iridium. Top. Curr. Chem. 2007, 281, 143.

(3) You, Y.; Park, S. Y. Phosphorescent iridium(iii) complexes: toward high phosphorescence quantum efficiency through ligand control. Dalton Trans. 2009, 1267.

(4) Ladouceur, S.; Zysman-Colman, E. A Comprehensive Survey of Cationic Iridium(III) Complexes Bearing Nontraditional Ligand Chelation Motifs. Eur. J. Inorg. Chem. 2013, 2013, 2985.

(5) Recent examples include the following: Ladouceur, S.; Swanick, K. N.; Gallagher-Duval, S.; Ding, Z.; Zysman-Colman, E. Strongly Blue Luminescent Cationic Iridium(III) Complexes with an Electron-Rich Ancillary Ligand: Evaluation of Their Optoelectronic and Electrochemiluminescence Properties. Eur. J. Inorg. Chem. 2013, 2013, 5329.

(6) Baranoff, E.; Yum, J.-H.; Graetzel, M.; Nazeeruddin, M. K. Cyclometallated iridium complexes for conversion of light into electricity and electricity into light. J. Organomet. Chem. 2009, 694, 2661.

(7) Darmawan, N.; Yang, C. H.; Mauro, M.; Raynal, M.; Heun, S.; Pan, J.; Buchholz, H.; Braunstein, P.; De Cola, L. Efficient near-UV 
emitters based on cationic bis-pincer iridium(III) carbene complexes. Inorg. Chem. 2013, 52, 10756.

(8) Ladouceur, S.; Fortin, D.; Zysman-Colman, E. Enhanced Luminescent Iridium(III) Complexes Bearing Aryltriazole Cyclometallated Ligands. Inorg. Chem. 2011, 50, 11514.

(9) Tamayo, A. B.; Garon, S.; Sajoto, T.; Djurovich, P. I.; Tsyba, I. M.; Bau, R; Thompson, M. E. Cationic Bis-cyclometalated Iridium(III) Diimine Complexes and Their Use in Efficient Blue, Green, and Red Electroluminescent Devices. Inorg. Chem. 2005, 44, 8723.

(10) He, L.; Duan, L.; Qiao, J.; Wang, R.; Wei, P.; Wang, L.; Qiu, Y. Blue-Emitting Cationic Iridium Complexes with 2-(1H-Pyrazol-1yl)pyridine as the Ancillary Ligand for Efficient Light-Emitting Electrochemical Cells. Adv. Funct. Mater. 2008, 18, 2123.

(11) He, L.; Duan, L.; Qiao, J.; Dong, G.; Wang, L.; Qiu, Y. Highly Efficient Blue-Green and White Light-Emitting Electrochemical Cells Based on a Cationic Iridium Complex with a Bulky Side Group. Chem. Mater. 2010, 22, 3535.

(12) Mydlak, M.; Bizzarri, C.; Hartmann, D.; Sarfert, W.; Schmid, G.; De Cola, L. Positively Charged Iridium(III) Triazole Derivatives as Blue Emitters for Light-Emitting Electrochemical Cells. Adv. Funct. Mater. 2010, 20, 1812.

(13) Chen, B.; Li, Y.; Yang, W.; Luo, W.; Wu, H. Efficient sky-blue and blue-green light-emitting electrochemical cells based on cationic iridium complexes using 1,2,4-triazole-pyridine as the ancillary ligand with cyanogen group in alkyl chain. Org. Electron. 2011, 12, 766.

(14) Yang, C.-H.; Beltran, J.; Lemaur, V.; Cornil, J.; Hartmann, D.; Sarfert, W.; Fröhlich, R.; Bizzarri, C.; De Cola, L. Iridium Metal Complexes Containing N-Heterocyclic Carbene Ligands for BlueLight-Emitting Electrochemical Cells. Inorg. Chem. 2010, 49, 9891.

(15) Kessler, F.; Costa, R. D.; Di Censo, D.; Scopelliti, R.; Ortí, E.; Bolink, H. J.; Meier, S.; Sarfert, W.; Gratzel, M.; Nazeeruddin, M. K.; Baranoff, E. Near-UV to red-emitting charged bis-cyclometallated iridium(iii) complexes for light-emitting electrochemical cells. Dalton Trans. 2012, 41, 180.

(16) Liao, C.-T.; Chen, H.-F.; Su, H.-C.; Wong, K.-T. Tailoring balance of carrier mobilities in solid-state light-emitting electrochemical cells by doping a carrier trapper to enhance device efficiencies. J. Mater. Chem. 2011, 21, 17855.

(17) Sivasubramaniam, V.; Brodkorb, F.; Hanning, S.; Loebl, H. P.; van Elsbergen, V.; Boerner, H.; Scherf, U.; Kreyenschmidt, M. Fluorine cleavage of the light blue heteroleptic triplet emitter FIrpic. J. Fluorine Chem. 2009, 130, 640.

(18) Lin, C.-H.; Chang, Y.-Y.; Hung, J.-Y.; Lin, C.-Y.; Chi, Y.; Chung, M.-W.; Lin, C.-L.; Chou, P.-T.; Lee, G.-H.; Chang, C.-H.; Lin, W.-C. Iridium(III) Complexes of a Dicyclometalated Phosphite Tripod Ligand: Strategy to Achieve Blue Phosphorescence Without Fluorine Substituents and Fabrication of OLEDs. Angew. Chem. 2011, 123, 3240.

(19) Tordera, D.; Bünzli, A. M.; Pertegás, A.; Junquera-Hernández, J. M.; Constable, E. C.; Zampese, J. A.; Housecroft, C. E.; Ortí, E.; Bolink, H. J. Efficient Green-Light-Emitting Electrochemical Cells Based on Ionic Iridium Complexes with Sulfone-Containing Cyclometalating Ligands. Chem. - Eur. J. 2013, 19, 8597.

(20) Constable, E. C.; Ertl, C. D.; Housecroft, C. E.; Zampese, J. A. Green-emitting iridium(iii) complexes containing sulfanyl- or sulfonefunctionalized cyclometallating 2-phenylpyridine ligands. Dalton Trans. 2014, 43, 5343.

(21) Grushin, V. V.; Herron, N.; LeCloux, D. D.; Marshall, W. J.; Petrov, V. A.; Wang, Y. New, efficient electroluminescent materials based on organometallic Ir complexes. Chem. Commun. 2001, 1494.

(22) Coppo, P.; Plummer, E. A.; De Cola, L. Tuning iridium(iii) phenylpyridine complexes in the "almost blue" region. Chem. Commun. 2004, 1774.

(23) Takizawa, S.-y.; Nishida, J.-i.; Tsuzuki, T.; Tokito, S.; Yamashita, Y. Phosphorescent Iridium Complexes Based on 2-Phenylimidazo[1,2a]pyridine Ligands: Tuning of Emission Color toward the Blue Region and Application to Polymer Light-Emitting Devices. Inorg. Chem. 2007, 46, 4308 .
(24) Xu, M.; Zhou, R.; Wang, G.; Xiao, Q.; Du, W.; Che, G. Synthesis and characterization of phosphorescent iridium complexes containing trifluoromethyl-substituted phenyl pyridine based ligands. Inorg. Chim. Acta 2008, 361, 2407.

(25) Sykes, D.; Tidmarsh, I. S.; Barbieri, A.; Sazanovich, I. V.; Weinstein, J. A.; Ward, M. D. $\mathrm{d} \rightarrow \mathrm{f}$ Energy Transfer in a Series of IrIII/EuIII Dyads: Energy-Transfer Mechanisms and White-Light Emission. Inorg. Chem. 2011, 50, 11323.

(26) Shavaleev, N. M.; Xie, G.; Varghese, S.; Cordes, D. B.; Slawin, A. M. Z.; Momblona, C.; Ortí, E.; Bolink, H. J.; Samuel, I. D. W.; Zysman-Colman, E. Green Phosphorescence and Electroluminescence of Sulfur Pentafluoride-Functionalized Cationic Iridium(III) Complexes. Inorg. Chem. 2015, 54, 5907.

(27) Lee, S. J.; Park, K.-M.; Yang, K.; Kang, Y. Blue Phosphorescent Ir(III) Complex with High Color Purity: fac-Tris $\left(2^{\prime}, 6^{\prime}\right.$-difluoro-2,3'bipyridinato-N,C4')iridium(III). Inorg. Chem. 2009, 48, 1030.

(28) Yang, C.-H.; Mauro, M.; Polo, F.; Watanabe, S.; Muenster, I.; Fröhlich, R.; De Cola, L. Deep-Blue-Emitting Heteroleptic Iridium(III) Complexes Suited for Highly Efficient Phosphorescent OLEDs. Chem. Mater. 2012, 24, 3684.

(29) Kessler, F.; Watanabe, Y.; Sasabe, H.; Katagiri, H.; Nazeeruddin, M. K.; Grätzel, M.; Kido, J. High-performance pure blue phosphorescent OLED using a novel bis-heteroleptic iridium(iii) complex with fluorinated bipyridyl ligands. J. Mater. Chem. C 2013, 1, 1070.

(30) Chang, C. H.; Wu, Z. J.; Chiu, C. H.; Liang, Y. H.; Tsai, Y. S.; Liao, J. L.; Chi, Y.; Hsieh, H. Y.; Kuo, T. Y.; Lee, G. H.; Pan, H. A.; Chou, P. T.; Lin, J. S.; Tseng, M. R. A new class of sky-blue-emitting Ir(III) phosphors assembled using fluorine-free pyridyl pyrimidine cyclometalates: application toward high-performance sky-blue- and white-emitting OLEDs. ACS Appl. Mater. Interfaces 2013, 5, 7341.

(31) Frey, J.; Curchod, B. F. E.; Scopelliti, R.; Tavernelli, I.; Rothlisberger, U.; Nazeeruddin, M. K.; Baranoff, E. Structure-property relationships based on Hammett constants in cyclometalated iridium(iii) complexes: their application to the design of a fluorine-free FIrPiclike emitter. Dalton Trans. 2014, 43, 5667.

(32) Evariste, S.; Sandroni, M.; Rees, T. W.; Roldan-Carmona, C.; Gil-Escrig, L.; Bolink, H. J.; Baranoff, E.; Zysman-Colman, E. Fluorinefree blue-green emitters for light-emitting electrochemical cells. J. Mater. Chem. C 2014, 2, 5793.

(33) Lee, J.; Oh, H.; Kim, J.; Park, K.-M.; Yook, K. S.; Lee, J. Y.; Kang, Y. Fluorine-free blue phosphorescent emitters for efficient phosphorescent organic light emitting diodes. J. Mater. Chem. C 2014, 2, 6040 .

(34) Henwood, A. F.; Bansal, A. K.; Cordes, D. B.; Slawin, A. M. Z.; Samuel, I. D. W.; Zysman-Colman, E. Solubilised bright blue-emitting iridium complexes for solution processed OLEDs. J. Mater. Chem. C 2016, 4, 3726.

(35) Henwood, A. F.; Evariste, S.; Slawin, A. M. Z.; Zysman-Colman, E. Rigid biimidazole ancillary ligands as an avenue to bright deep blue cationic iridium(iii) complexes. Faraday Discuss. 2014, 174, 165.

(36) Yun, S.-J.; Seo, H.-J.; Song, M.; Jin, S.-H.; Kim, Y. I. Blue Emitting Cationic Iridium Complexes Containing Two Substituted 2Phenylpyridine and One 2,2'-Biimidazole for Solution-Processed Organic Light-Emitting Diodes (OLEDs). Bull. Korean Chem. Soc. 2012, 33, 3645.

(37) Meier, S. B.; Sarfert, W.; Junquera-Hernández, J. M.; Delgado, M.; Tordera, D.; Ortí, E.; Bolink, H. J.; Kessler, F.; Scopelliti, R.; Grätzel, M.; Nazeeruddin, M. K.; Baranoff, E. A deep-blue emitting charged bis-cyclometallated iridium(iii) complex for light-emitting electrochemical cells. J. Mater. Chem. C 2013, 1, 58.

(38) Orselli, E.; Kottas, G. S.; Konradsson, A. E.; Coppo, P.; Fröhlich, R.; De Cola, L.; van Dijken, A.; Büchel, M.; Börner, H. Blue-Emitting Iridium Complexes with Substituted 1,2,4-Triazole Ligands:, $\ddot{\text { Ââ }}$ Synthesis, Photophysics, and Devices. Inorg. Chem. 2007, 46, 11082.

(39) Yang, C.-H.; Cheng, Y.-M.; Chi, Y.; Hsu, C.-J.; Fang, F.-C.; Wong, K.-T.; Chou, P.-T.; Chang, C.-H.; Tsai, M.-H.; Wu, C.-C. BlueEmitting Heteroleptic Iridium(III) Complexes Suitable for High- 
Efficiency Phosphorescent OLEDs. Angew. Chem., Int. Ed. 2007, 46, 2418.

(40) Fernandez-Hernandez, J. M.; Ladouceur, S.; Shen, Y.; Iordache, A.; Wang, X.; Donato, L.; Gallagher-Duval, S.; de Anda Villa, M.; Slinker, J. D.; De Cola, L.; Zysman-Colman, E. Blue light emitting electrochemical cells incorporating triazole-based luminophores. J. Mater. Chem. C 2013, 1, 7440.

(41) For a recent review on LEECs and a perspective on current design challenges see: Hu, T.; He, L.; Duan, L.; Qiu, Y. Solid-state light-emitting electrochemical cells based on ionic iridium(iii) complexes. J. Mater. Chem. 2012, 22, 4206.

(42) Hansch, C.; Leo, A.; Taft, R. W. A survey of Hammett substituent constants and resonance and field parameters. Chem. Rev. 1991, 91, 165.

(43) Shavaleev, N. M.; Monti, F.; Costa, R. D.; Scopelliti, R.; Bolink, H. J.; Ortí, E.; Accorsi, G.; Armaroli, N.; Baranoff, E.; Grätzel, M.; Nazeeruddin, M. K. Bright Blue Phosphorescence from Cationic BisCyclometalated Iridium(III) Isocyanide Complexes. Inorg. Chem. 2012, 51, 2263.

(44) Kawamura, Y.; Brooks, J.; Brown, J. J.; Sasabe, H.; Adachi, C. Intermolecular Interaction and a Concentration-Quenching Mechanism of Phosphorescent Ir(III) Complexes in a Solid Film. Phys. Rev. Lett. 2006, 96, 017404.

(45) Babudri, F.; Farinola, G. M.; Naso, F.; Ragni, R. Fluorinated organic materials for electronic and optoelectronic applications: the role of the fluorine atom. Chem. Commun. 2007, 1003.

(46) Chou, P.-T.; Chi, Y. Phosphorescent Dyes for Organic LightEmitting Diodes. Chem. - Eur. J. 2007, 13, 380.

(47) Leung, S. K.; Liu, H. W.; Lo, K. K. Functionalization of luminescent cyclometalated iridium(III) polypyridine complexes with a fluorous moiety: photophysics, protein-binding, bioconjugation, and cellular uptake properties. Chem. Commun. 2011, 47, 10548.

(48) Xiao, L.; Chen, Z.; Qu, B.; Luo, J.; Kong, S.; Gong, Q.; Kido, J. Recent Progresses on Materials for Electrophosphorescent Organic Light-Emitting Devices. Adv. Mater. 2011, 23, 926.

(49) Hu, T.; He, L.; Duan, L.; Qiu, Y. Solid-state light-emitting electrochemical cells based on ionic iridium(iii) complexes. J. Mater. Chem. 2012, 22, 4206.

(50) Stille, J. K. The Palladium-Catalyzed Cross-Coupling Reactions of Organotin Reagents with Organic Electrophiles [New Synthetic Methods (58)]. Angew. Chem., Int. Ed. Engl. 1986, 25, 508.

(51) Shavaleev, N. M.; Monti, F.; Scopelliti, R.; Armaroli, N.; Grätzel, M.; Nazeeruddin, M. K. Blue Phosphorescence of Trifluoromethyland Trifluoromethoxy-Substituted Cationic Iridium(III) Isocyanide Complexes. Organometallics 2012, 31, 6288.

(52) Harrowven, D. C.; Curran, D. P.; Kostiuk, S. L.; Wallis-Guy, I. L.; Whiting, S.; Stenning, K. J.; Tang, B.; Packard, E.; Nanson, L. Potassium carbonate-silica: a highly effective stationary phase for the chromatographic removal of organotin impurities. Chem. Commun. 2010, 46, 6335.

(53) Nonoyama, M. Benzo[h] quinolin-10-yl-N Iridium(III) Complexes. Bull. Chem. Soc. Jpn. 1974, 47, 767.

(54) Costa, R. D.; Ortì, E.; Bolink, H. J.; Graber, S.; Schaffner, S.; Neuburger, M.; Housecroft, C. E.; Constable, E. C. Archetype Cationic Iridium Complexes and Their Use in Solid-State Light-Emitting Electrochemical Cells. Adv. Funct. Mater. 2009, 19, 3456.

(55) Pavlishchuk, V. V.; Addison, A. W. Conversion constants for redox potentials measured versus different reference electrodes in acetonitrile solutions at $25^{\circ} \mathrm{C}$. Inorg. Chim. Acta 2000, 298, 97.

(56) Lyu, Y.-Y.; Byun, Y.; Kwon, O.; Han, E.; Jeon, W. S.; Das, R. R.; Char, K. Substituent Effect on the Luminescent Properties of a Series of Deep Blue Emitting Mixed Ligand Ir(III) Complexes. J. Phys. Chem. B 2006, 110, 10303.

(57) For examples see: Ladouceur, S.; Fortin, D.; Zysman-Colman, E. Enhanced Luminescent Iridium(III) Complexes Bearing Aryltriazole Cyclometallated Ligands. Inorg. Chem. 2011, 50, 11514.

(58) Shavaleev, N. M.; Scopelliti, R.; Grätzel, M.; Nazeeruddin, M. K.; Pertegás, A.; Roldán-Carmona, C.; Tordera, D.; Bolink, H. J. Pulsed-current versus constant-voltage light-emitting electrochemical cells with trifluoromethyl-substituted cationic iridium(iii) complexes. J. Mater. Chem. C 2013, 1, 2241.

(59) Chiu, Y.-C.; Hung, J.-Y.; Chi, Y.; Chen, C.-C.; Chang, C.-H.; Wu, C.-C.; Cheng, Y.-M.; Yu, Y.-C.; Lee, G.-H.; Chou, P.-T. En Route to High External Quantum Efficiency $(\sim 12 \%)$, Organic True-BlueLight-Emitting Diodes Employing Novel Design of Iridium (III) Phosphors. Adv. Mater. 2009, 21, 2221.

(60) Lowry, M. S.; Hudson, W. R.; Pascal, R. A., Jr.; Bernhard, S. Accelerated Luminophore Discovery through Combinatorial Synthesis. J. Am. Chem. Soc. 2004, 126, 14129.

(61) Ladouceur, S.; Fortin, D.; Zysman-Colman, E. The role of substitution on the photophysical propertiesof 5,5'-diaryl-2,2'bipyridine (bpy*) in [Ir(ppy)2(bpy*)]PF6 complexes: A combined experimental and theoretical study. Inorg. Chem. 2010, 49, 5625.

(62) Waern, J. B.; Desmarets, C.; Chamoreau, L.-M.; Amouri, H.; Barbieri, A.; Sabatini, C.; Ventura, B.; Barigelletti, F. Luminescent Cyclometalated RhIII, IrIII, and (DIP)2RuII Complexes with Carboxylated Bipyridyl Ligands: Synthesis, X-ray Molecular Structure, and Photophysical Properties. Inorg. Chem. 2008, 47, 3340.

(63) The reported complex is $\left.\left[\mathrm{ppy}-\mathrm{F}_{2}\right)_{2} \operatorname{Ir}(\mathrm{dtBubpy})\right]^{+}$, where ppy- $\mathrm{F}_{2}$ is 2,4-difluorophenylpyridinato. Bolink, H. J.; Coronado, E.; Costa, R. n. D.; Lardiés, N.; Orti, E. Near-Quantitative Internal Quantum Efficiency in a Light-Emitting Electrochemical Cell. Inorg. Chem. 2008, 47, 9149.

(64) Tamayo, A. B.; Alleyne, B. D.; Djurovich, P. I.; Lamansky, S.; Tsyba, I.; Ho, N. N.; Bau, R.; Thompson, M. E. Synthesis and Characterization of Facial and Meridional Tris-cyclometalated Iridium(III) Complexes. J. Am. Chem. Soc. 2003, 125, 7377.

(65) Lamansky, S.; Djurovich, P.; Murphy, D.; Abdel-Razzaq, F.; Lee, H.-E.; Adachi, C.; Burrows, P. E.; Forrest, S. R.; Thompson, M. E. Highly Phosphorescent Bis-Cyclometalated Iridium Complexes: Synthesis, Photophysical Characterization, and Use in Organic Light Emitting Diodes. J. Am. Chem. Soc. 2001, 123, 4304.

(66) Melhuish, W. H. Quantum Efficiences Of Fluorescence Of Organic Substances: Effect Of Solvent And Concentration Of The Fluorescent Solute 1. J. Phys. Chem. 1961, 65, 229.

(67) Lo, K. K.-W.; Chan, J. S.-W.; Lui, L.-H.; Chung, C.-K. Novel Luminescent Cyclometalated Iridium(III) Diimine Complexes That Contain a Biotin Moiety. Organometallics 2004, 23, 3108.

(68) Parker, S. T.; Slinker, J. D.; Lowry, M. S.; Cox, M. P.; Bernhard, S.; Malliaras, G. G. Improved Turn-on Times of Iridium Electroluminescent Devices by Use of Ionic Liquids. Chem. Mater. 2005, 17, 3187.

(69) Zysman-Colman, E.; Slinker, J. D.; Parker, J. B.; Malliaras, G. G.; Bernhard, S. Improved Turn-On Times of Light-Emitting Electrochemical Cells. Chem. Mater. 2008, 20, 388.

(70) Costa, R. D.; Pertegás, A.; Ortí, E.; Bolink, H. J. Improving the Turn-On Time of Light-Emitting Electrochemical Cells without Sacrificing their Stability. Chem. Mater. 2010, 22, 1288.

(71) Tordera, D.; Meier, S.; Lenes, M.; Costa, R. D.; Ortí, E.; Sarfert, W.; Bolink, H. J. Simple, Fast, Bright, and Stable Light Sources. Adv. Mater. 2012, 24, 897.

(72) Zhang, J.; Zhou, L.; Al-Attar, H. A.; Shao, K.; Wang, L.; Zhu, D.; $\mathrm{Su}, \mathrm{Z}$.; Bryce, M. R.; Monkman, A. P. Efficient Light-Emitting Electrochemical Cells (LECs) Based on Ionic Iridium(III) Complexes with 1,3,4-Oxadiazole Ligands. Adv. Funct. Mater. 2013, 23, 4667.

(73) Meier, S. B.; Hartmann, D.; Tordera, D.; Bolink, H. J.; Winnacker, A.; Sarfert, W. Dynamic doping and degradation in sandwich-type light-emitting electrochemical cells. Phys. Chem. Chem. Phys. 2012, 14, 10886.

(74) Gao, J.; Dane, J. Visualization of electrochemical doping and light-emitting junction formation in conjugated polymer films. Appl. Phys. Lett. 2004, 84, 2778.

(75) Wong, M. Y.; Hedley, G. J.; Xie, G.; Kölln, L. S.; Samuel, I. D. W.; Pertegás, A.; Bolink, H. J.; Zysman-Colman, E. Light-Emitting Electrochemical Cells and Solution-Processed Organic Light-Emitting Diodes Using Small Molecule Organic Thermally Activated Delayed Fluorescence Emitters. Chem. Mater. 2015, 27, 6535. 
(76) CrystalClear-SM Expert v. 2.1; Rigaku Corporation: Tokyo, Japan, 2010-2014.

(77) Beurskens, P. T.; Beurskens, G.; de Gelder, R.; Garcia-Granda, S.; Gould, R. O.; Israel, R.; Smits, J. M. M. DIRDIF-99; University of Nijmegen: Nijmegen, The Netherlands, 1999.

(78) Sheldrick, G. Crystal structure refinement with SHELXL. Acta Crystallogr., Sect. A: Found. Adv. 2015, 71, 3.

(79) CrystalStructure v4.1; Rigaku Corporation: Tokyo, Japan, 2014. (80) Crosby, G. A.; Demas, J. N. Measurement of photoluminescence quantum yields. Review. J. Phys. Chem. 1971, 75, 991. 